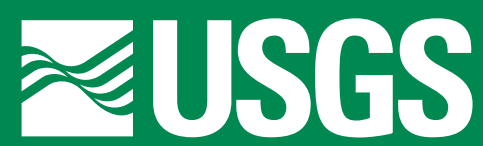

\title{
Hydrology and Simulation of Ground-Water Flow, Lake Point, Tooele County, Utah
}

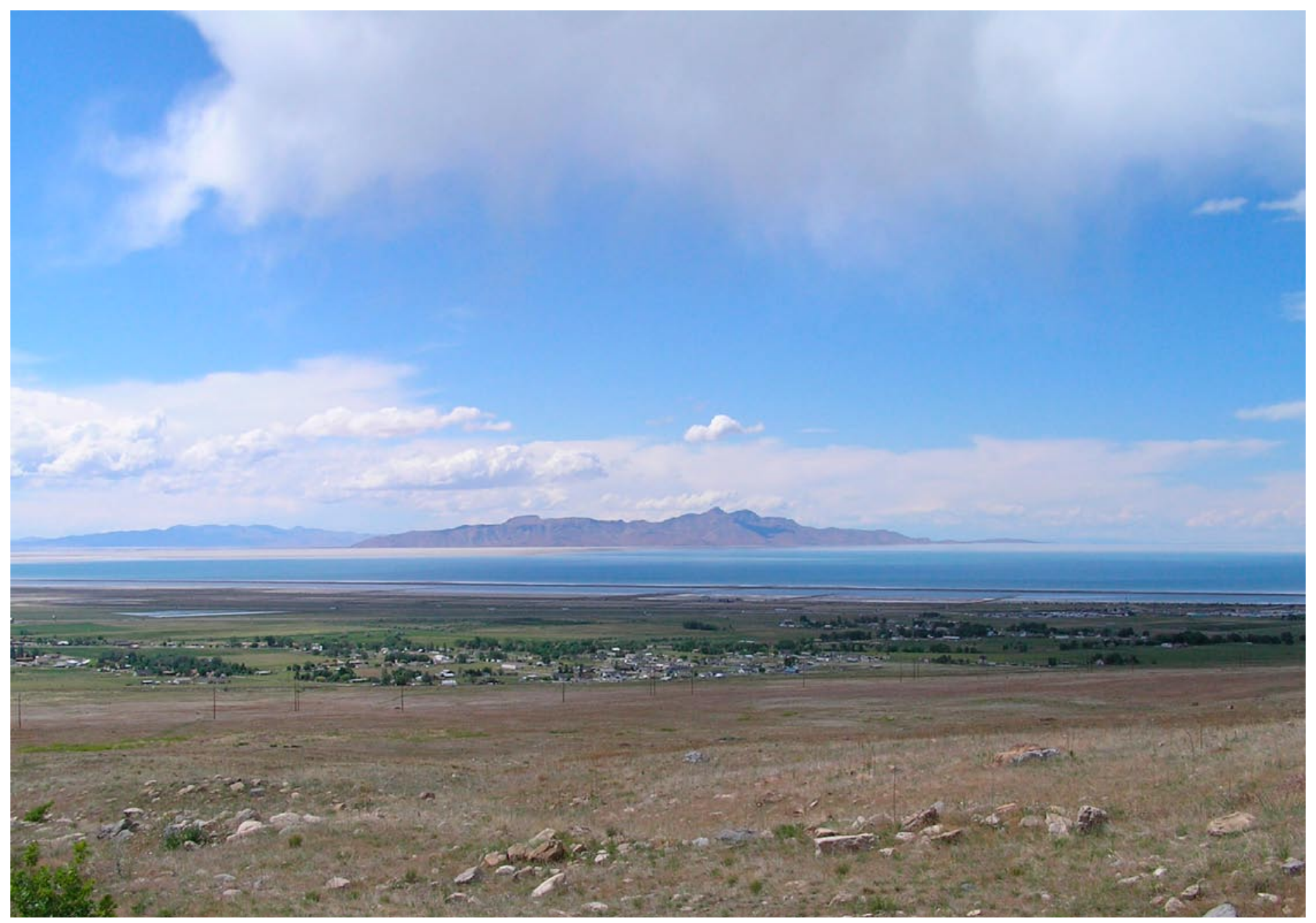

Prepared in cooperation with the TOOELE COUNTY; UTAH DEPARTMENT OF NATURAL RESOURCES, DIVISION OF WATER RIGHTS; AND LAKE POINT IMPROVEMENT DISTRICT

\section{Scientific Investigations Report 2006-5310}


Cover: Lake Point, Utah. Photo by Brent Jorgensen, U.S. Geological Survey. 


\title{
Hydrology and Simulation of Ground-Water Flow, Lake Point, Tooele County, Utah
}

\author{
By Lynette E. Brooks
}

Prepared in cooperation with

Tooele County; Utah Department of Natural Resources, Division of Water Rights; and Lake Point Improvement District

Scientific Investigations Report 2006-5310 


\title{
U.S. Department of the Interior \\ DIRK KEMPTHORNE, Secretary
}

\author{
U.S. Geological Survey \\ Mark D. Myers, Director
}

U.S. Geological Survey, Reston, Virginia: 2006

For product and ordering information:

World Wide Web: http://www.usgs.gov/pubprod

Telephone: 1-888-ASK-USGS

For more information on the USGS--the Federal source for science about the Earth, its natural and living resources, natural hazards, and the environment:

World Wide Web: http://www.usgs.gov

Telephone: 1-888-ASK-USGS

Any use of trade, product, or firm names is for descriptive purposes only and does not imply endorsement by the U.S. Government.

Although this report is in the public domain, permission must be secured from the individual copyright owners to reproduce any copyrighted materials contained within this report. 


\section{Contents}

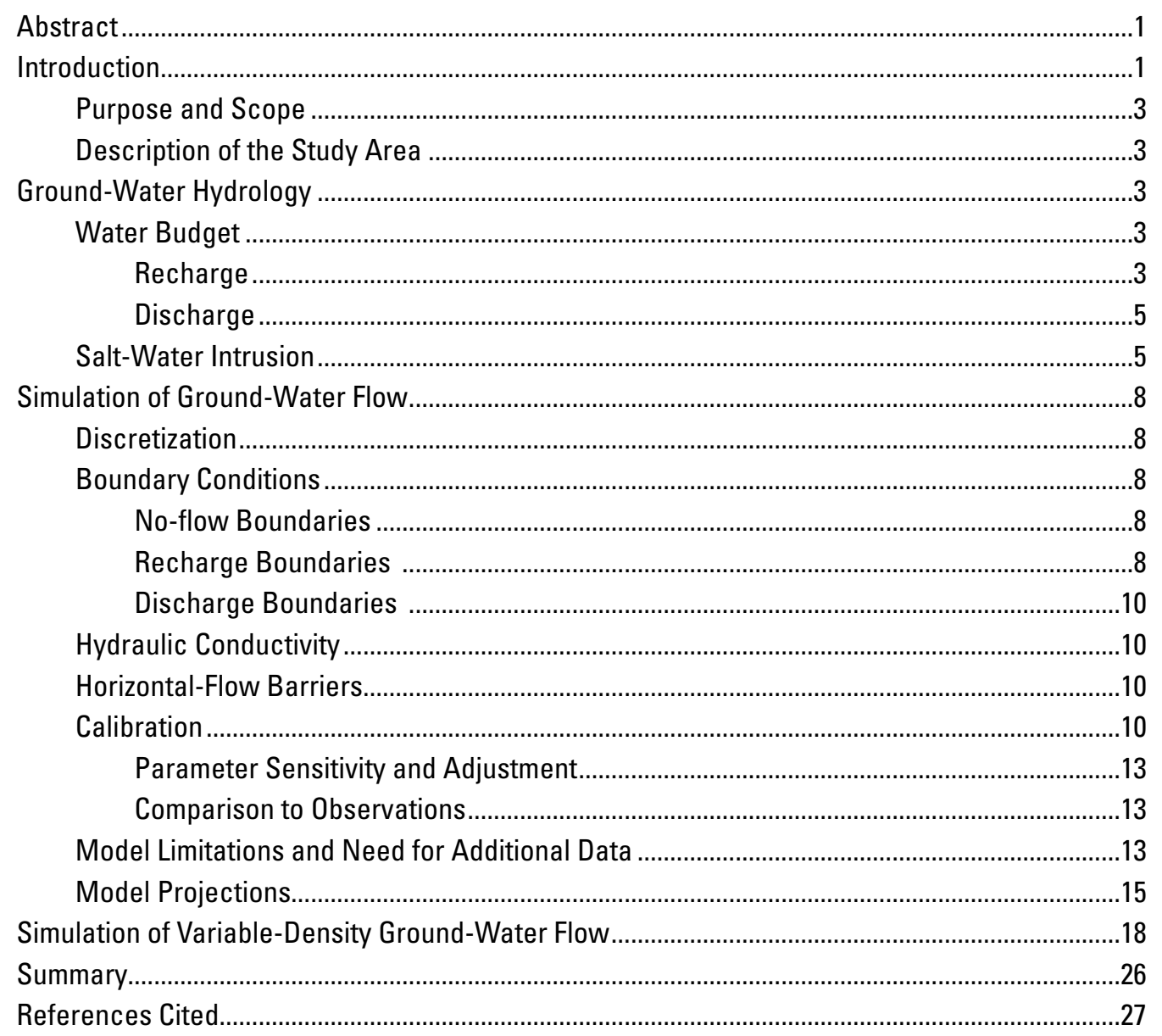




\section{Figures}

1. Location of Lake Point study area, Tooele County, Utah.......................................................

2. Numbering system for hydrologic-data sites in Utah......................................................

3. Average annual precipitation for Tooele Valley and northern Rush Valley, Tooele County, Utah, 1971-2000. 6

4. Generalized pattern of salt-water intrusion from Great Salt Lake, Lake Point, Tooele County, Utah...

5. Model grid, simulated constant-head boundaries, area of model layer 1, budget zones, and horizontal-flow barriers in the ground-water flow model, Lake Point, Tooele County, Utah.

6. Distribution of withdrawal from wells simulated in the ground-water flow model, Lake Point, Tooele County, Utah.

7. (a) Hydraulic conductivity of coarse material in unconsolidated basin fill, (b) percent of coarse material in basin fill, (c) simulated hydraulic conductivity of unconsolidated basin fill, and (d) simulated hydraulic conductivity of consolidated rock in the ground-water flow models, Lake Point, Tooele County, Utah

8. Ground-water altitude simulated in layer 2 of the steady-state ground-water flow model, and difference between simulated ground-water altitude and selected ground-water altitudes measured in March 1969 and March 2002, Lake Point, Tooele County, Utah

9. Simulated drawdown in model layer 3, projection 1 of the ground-water flow model, Lake Point area, Tooele County, Utah.

10. Simulated drawdown in model layer 4, projection 2 of the ground-water flow model, Lake Point area, Tooele County, Utah.

11. Simulated change in water-budget components to meet increased withdrawal for (a) projection 1 and (b) projection 2 of the ground-water flow model, Lake Point area, Tooele County, Utah

12. Relation of SUTRA mesh to MODFLOW-2000 grid and location of SUTRA nodes simulating Great Salt Lake, Lake Point, Tooele County, Utah

13. Simulated dissolved-solids concentration in ground water caused by salt-water intrusion with 2002 flow conditions, Lake Point area, Tooele County, Utah..

14. Simulated steady-state and 2002 measured dissolved-solids concentration, Lake Point area, Tooele County, Utah.

15. Simulated increase in dissolved-solids concentration over 2002 steady-state conditions caused by increasing withdrawals, bottom of model layer 2, Lake Point area, Tooele County, Utah.

16. Simulated increase in dissolved-solids concentration over 2002 steady-state conditions caused by increasing withdrawals, bottom of model layer 4, Lake Point area, Tooele County, Utah 


\section{Tables}

1. Annual ground-water budget, Lake Point, Tooele County, Utah..........................................5

2. Simulated water budgets, Lake Point area, Tooele County, Utah......................................15

3. Values of fluid and solid properties used in SUTRA simulations, Lake Point area, Tooele County, Utah.

\section{Conversion Factors, Datums, and Abbreviated Water-Quality} Units

\begin{tabular}{|c|c|c|}
\hline Multiply & By & To obtain \\
\hline \multicolumn{3}{|c|}{ Length } \\
\hline foot (ft) & 0.3048 & meter \\
\hline inch (in.) & 2.54 & centimeter \\
\hline inch (in.) & 25.4 & millimeter \\
\hline mile (mi) & 1.609 & kilometer \\
\hline \multicolumn{3}{|c|}{ Area } \\
\hline acre & 4,047 & square meter \\
\hline acre & 0.4047 & square hectometer \\
\hline acre & 0.004047 & square kilometer \\
\hline square mile $\left(\mathrm{mi}^{2}\right)$ & 2.590 & square kilometer \\
\hline & Volume & \\
\hline acre-foot (acre-ft) & 1,233 & cubic meter \\
\hline \multicolumn{3}{|c|}{ Flow rate, velocity, and transmissivity } \\
\hline acre-foot per year (acre-ft/yr) & 1,233 & cubic meter per year \\
\hline acre-foot per year (acre-ft/yr) & 0.001233 & cubic hectometer per year \\
\hline foot per day $(\mathrm{ft} / \mathrm{d})$ & 0.3048 & meter per day \\
\hline foot squared per day $\left(\mathrm{ft}^{2} / \mathrm{d}\right)$ & 0.09290 & meter squared per day \\
\hline \multicolumn{3}{|c|}{ Permeability' } \\
\hline foot squared $\left(\mathrm{ft}^{2}\right)$ & 0.09290 & meter squared \\
\hline \multicolumn{3}{|c|}{ Fluid pressure ${ }^{2}$} \\
\hline $\begin{array}{l}\text { pounds per foot-second squared } \\
\left(\mathrm{lb} / \mathrm{ft}-\mathrm{s}^{2}\right)\end{array}$ & 1.488164 & $\begin{array}{l}\text { kilogram per meter-second } \\
\text { squared }\end{array}$ \\
\hline \multicolumn{3}{|c|}{ Fluid density } \\
\hline pounds per cubic foot $\left(\mathrm{lb} / \mathrm{ft}^{3}\right)$ & 0.0160185 & kilogram per liter \\
\hline
\end{tabular}

Vertical coordinate information is referenced to the National Geodetic Vertical Datum of 1929 (NGVD 1929). Altitude, as used in this report, refers to distance above the vertical datum. Horizontal coordinate information is referenced to the North American Datum of 1983 (NAD 83).

Temperature is reported in degrees Celsius $\left({ }^{\circ} \mathrm{C}\right)$ or degrees Fahrenheit $\left({ }^{\circ} \mathrm{F}\right)$. Each temperature scale can be converted to the other by using the following equations:

$$
\begin{aligned}
& { }^{\circ} \mathrm{F}=1.8\left({ }^{\circ} \mathrm{C}\right)+32 \\
& { }^{\circ} \mathrm{C}=\left({ }^{\circ} \mathrm{F}-32\right) / 1.8
\end{aligned}
$$


Permeability and fluid pressure were used in the variable-density model instead of hydraulic conductivity and hydraulic head, which typically are used in constant-density advective flow models.

'Permeability (k) was derived from hydraulic conductivity (K), fluid dynamic viscosity $(\mu)$, fluid density ( $\rho)$, and gravity ( $\mathrm{g}$ ) as follows:

$$
\mathrm{k}=(\mathrm{K} x \mu) /(\rho \times g) \text {. }
$$

Resulting units for permeabililty in this report are meters squared $\left(\mathrm{m}^{2}\right)$.

${ }^{2}$ Fluid pressure (p) was derived from hydraulic head (h), elevation head (z), gravity (g), and fluid density $(\rho)$ as follows:

$$
p=(h-z) \times g \times \rho .
$$

Resulting units for fluid pressure in this report are kilograms per meter second squared $\left(\mathrm{kg} / \mathrm{ms}^{2}\right)$

Specific conductance is reported in microsiemens per centimeter at 25 degrees Celsius ( $\mu \mathrm{S}$ ) $\mathrm{cm})$.

Chemical concentration, fluid density, fluid viscosity, and fluid-density change are reported only in International System (SI) units. Chemical concentration in water generally is reported in milligrams per liter (mg/L) or micrograms per liter $(\mu \mathrm{g} / \mathrm{L})$. These units express the concentration of chemical constituents in solution as weight (grams) of solute per unit volume (liter) of water. A liter of water is assumed to weigh 1 kilogram. For concentrations less than $7,000 \mathrm{mg} / \mathrm{L}$, the numerical value in milligrams per liter is equivalent to concentration expressed as parts per million. Exceptions to this assumption include brines and water at high temperatures, both of which result in changes to the density of water. Fluid density is reported in kilograms per cubic meter $\left(\mathrm{kg} / \mathrm{m}^{3}\right)$. Fluid viscosity is reported in kilograms per meter-second $(\mathrm{kg} / \mathrm{ms})$. Fluid-density change is reported in kilograms per cubic meter. 


\title{
Hydrology and Simulation of Ground-Water Flow, Lake Point, Tooele County, Utah
}

\author{
By Lynette E. Brooks
}

\section{Abstract}

Water for new residential development in Lake Point, Utah may be supplied by public-supply wells completed in consolidated rock on the east side of Lake Point. Groundwater flow models were developed to help understand the effect the proposed withdrawal will have on water levels, flowing-well discharge, spring discharge, and ground-water quality in the study area. This report documents the conceptual and numerical ground-water flow models for the Lake Point area.

The ground-water system in the Lake Point area receives recharge from local precipitation and irrigation, and from ground-water inflow from southwest of the area. Ground water discharges mostly to springs. Discharge also occurs to evapotranspiration, wells, and Great Salt Lake. Even though ground water discharges to Great Salt Lake, dense salt water from the lake intrudes under the less-dense ground water and forms a salt-water wedge under the valley. This salt water is responsible for some of the high dissolved-solids concentrations measured in ground water in Lake Point.

A steady-state MODFLOW-2000 ground-water flow model of Tooele Valley adequately simulates water levels, ground-water discharge, and ground-water flow direction observed in Lake Point in 1969 and 2002. Simulating an additional 1,650 acre-feet per year withdrawal from wells causes a maximum projected drawdown of about 550 feet in consolidated rock near the simulated wells and drawdown exceeding 80 feet in an area encompassing most of the Oquirrh Mountains east of Lake Point. Drawdown in most of Lake Point ranges from 2 to $10 \mathrm{ft}$, but increases to more than 40 feet in the areas proposed for residential development. Discharge to Factory Springs, flowing wells, evapotranspiration, and Great Salt Lake is decreased by about 1,100 acre-feet per year (23 percent).

The U.S. Geological Survey SUTRA variable-density ground-water flow model generates a reasonable approximation of 2002 dissolved-solids concentration when simulating 2002 withdrawals. At most locations with measured dissolvedsolids concentration in excess of 1,000 milligrams per liter, the model simulates salt-water intrusion with similar concentrations.

Simulating an additional 1,650 acre-feet per year withdrawal increased simulated dissolved-solids concentration by 200 to 1,000 milligrams per liter throughout much of Lake Point and near Factory Springs at a depth of about 250 to
300 feet below land surface. The increase in dissolved-solids concentration with increased withdrawals is greater at a depth of about 700 to 800 feet and exceeds 1,000 milligrams per liter throughout most of Lake Point. At the north end of Lake Point, increases exceed 10,000 milligrams per liter.

\section{Introduction}

Lake Point is a small, rural community of about 1,000 residents located in the northeastern corner of Tooele County, Utah (fig. 1). Lake Point is experiencing growth and potential large-scale residential development as a bedroom community of Salt Lake City, Utah. Ground water is the source of drinking water for the area and a clear understanding of the hydrologic system and the amount and quality of ground water is critical to water managers.

The U.S. Geological Survey (USGS), in cooperation with Tooele County; Utah Department of Natural Resources, Division of Water Rights; and Lake Point Improvement District investigated the ground-water hydrology of Lake Point to provide knowledge for management of the area's groundwater resources. The objectives of the investigation were to determine (1) ground-water flow directions; (2) the pattern and magnitude of water-level fluctuations; (3) water-quality conditions in consolidated rock and basin fill; (4) the effects of ground-water withdrawals on water levels, flowing wells, and springs; (5) the effects of ground-water withdrawals on ground-water flow direction; and (6) the effects of groundwater withdrawals on water quality.

Some of the water for new residential development may be supplied by public-supply wells completed in consolidated rock on the east side of Lake Point. The ground-water withdrawal from these wells will need to be as much as 1,700 acre-ft/yr to provide water for as many as to 2,000 residences (Randy Cassidy, Oquirrh Mountain Water Company, oral commun., 2005). To help understand the effect the proposed withdrawal will have on water levels, flowing-well discharge, and spring discharge in Lake Point, a ground-water flow model being developed by the USGS for Tooele Valley was used to estimate possible changes to the ground-water system. A separate variable-density flow model of the Lake Point area was developed as part of this study to assess the extent of saltwater intrusion from Great Salt Lake and changes in salt-water intrusion as a result of the proposed ground-water withdrawal. 


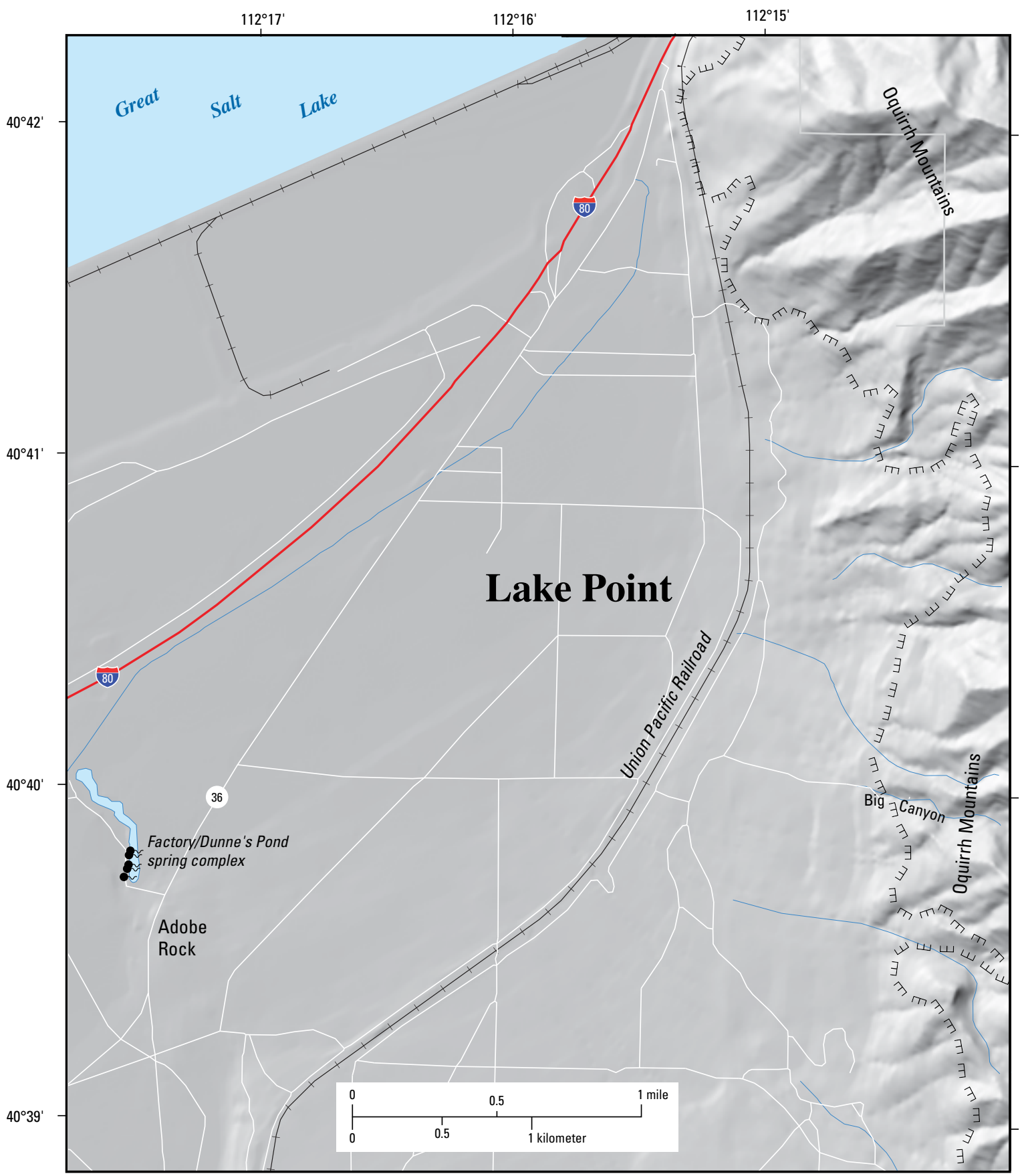

Base from U.S. Geological Survey digital line graph data, $1972,1: 24,000$

Universal Transverse Mercator projection, Zone 12

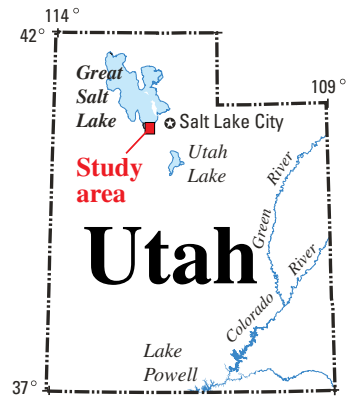

\section{EXPLANATION}

$\sqcup \sqcup$ Approximate boundary of basin-fill deposits

or Spring

Figure 1. Location of Lake Point study area, Tooele County, Utah. 


\section{Purpose and Scope}

This report provides a description of the ground-water budget in the Lake Point area, description of salt-water intrusion, description of the numerical models, and results from the numerical models. This is a preliminary report; both the conceptual understanding and the numerical models may change upon completion of a larger Tooele Valley study. Because additional data collection and calibration may cause changes in the regional model, the MODFLOW-2000 model used for this report is not available to the public at this time (2007). Changes to the model are not expected to substantially change the conclusions of this report. The SUTRA model is also considered to be a preliminary product used for hypothesis testing, but is available to the public from the USGS Utah Water Science Center.

\section{Description of the Study Area}

Lake Point, as used in this report, refers to the approximately $6-\mathrm{mi}^{2}$ ground-water basin delineated on the north by Great Salt Lake, on the east by the topographic divide of the Oquirrh Mountains, and on the south by a bedrock extension from the Oquirrh Mountains. The basin fill is composed of unconsolidated deposits consisting of sand, gravel, silt, clay, and minor volcanic detritus and ash. The Oquirrh Mountains are composed mainly of quartzite and limestone of the Oquirrh Formation (Lambert and Stolp, 1999, p. 5). No perennial and only a small amount of ephemeral streamflow enters the Lake Point area. The numbering system for hydrologic-data sites is shown in figure 2.

\section{Ground-Water Hydrology}

Ground water in Tooele Valley flows from the recharge areas in and near the surrounding mountains toward several large springs, areas of evapotranspiration, and Great Salt Lake at the north end of the valley. Four large springs discharge about 24 percent of the ground water in the valley (Lambert and Stolp, 1999, table 6). Two of these springs, Mill Pond Springs (southwest of study area) and Factory Springs (fig. 1) are near the western edge of Lake Point and affect groundwater flow through the Lake Point area. Mill Pond Spring probably does not receive water directly from the Lake Point area, but captures most water moving north toward the area. Water levels in Lake Point indicate that much of Lake Point contributes water to Factory Springs (Kenney and others, 2006).

Most of the recharge to the Lake Point area occurs east of Lake Point and moves through consolidated rock and into unconsolidated basin fill. Some water may move north through consolidated rock to discharge to Great Salt Lake and springs near the lake. Few data are available describing the hydrologic properties of the consolidated rock, but it is probable that the properties vary widely across small areas because of faulting and fracturing. Estimates of hydraulic-conductivity values of consolidated rock in Lake Point made from specific-capacity data range from 0.3 to $1.3 \mathrm{ft} / \mathrm{d}$. A numerical ground-water flow model of the ground-water system in the Oquirrh Mountains used values of horizontal and vertical hydraulic conductivity ranging from 0.001 to $1 \mathrm{ft} / \mathrm{d}$ (TriTechnics Corporation, written commun., 1996, table 2).

The unconsolidated basin fill consists of intermixed and layered gravel, sand, silt, and clay. In general, the fill consists of more sand and gravel near the mountains and more silt and clay near Great Salt Lake (Lambert and Stolp, 1999, fig. 6). Colluvial deposits near the mountains decrease the hydraulic conductivity in some areas (Lambert and Stolp, 1999, fig. 17). Distinct continuous clay layers probably do not exist, but clay lenses confine the ground water in the deeper parts of the basin fill, creating an upward hydraulic gradient that results in flowing wells in part of the study area. Estimates of hydraulic-conductivity values of unconsolidated basin fill in Lake Point made from specific-capacity data range from 3 to 500 $\mathrm{ft} / \mathrm{d}$. Estimates of vertical hydraulic-conductivity values have not been made, but vertical-hydraulic conductivity values in nearby Salt Lake Valley range from $5.1 \times 10^{-5}$ to $1 \mathrm{ft} / \mathrm{d}$ (Lambert and Stolp, 1999, p. 13).

No geologic or topographic feature divides the Lake Point area from the rest of Tooele Valley on the west side and a small amount of ground water flows from Lake Point across this border. Ground water flows through consolidated rock into Lake Point across the southwestern boundary of the study area.

\section{Water Budget}

Ground-water recharge in Lake Point occurs from local precipitation and irrigation, and as subsurface inflow from southwest of the area (table 1). Ground-water discharge in Lake Point is mostly to Factory Springs. Other discharge is to Great Salt Lake, by evapotranspiration, to wells, and as subsurface outflow to the west of the study area, and composes about 30 percent of the discharge in Lake Point.

\section{Recharge}

Recharge from direct infiltration of precipitation provides all of the recharge to consolidated rock, but less than 15 percent of the recharge to the unconsolidated deposits in Tooele Valley (Lambert and Stolp, 1999, table 6). The amount and distribution of this recharge controls water levels and groundwater movement throughout the valley. One of the objectives of the regional study was to determine a better estimate of recharge from precipitation, especially in the mountains. In semi-arid basins, it is likely that the area contributing most recharge is a relatively small part of the basin and that years with greater-than-average precipitation provide the most recharge (Flint, Flint, Hevesi, Blainey, Haltom, and Curtis, 


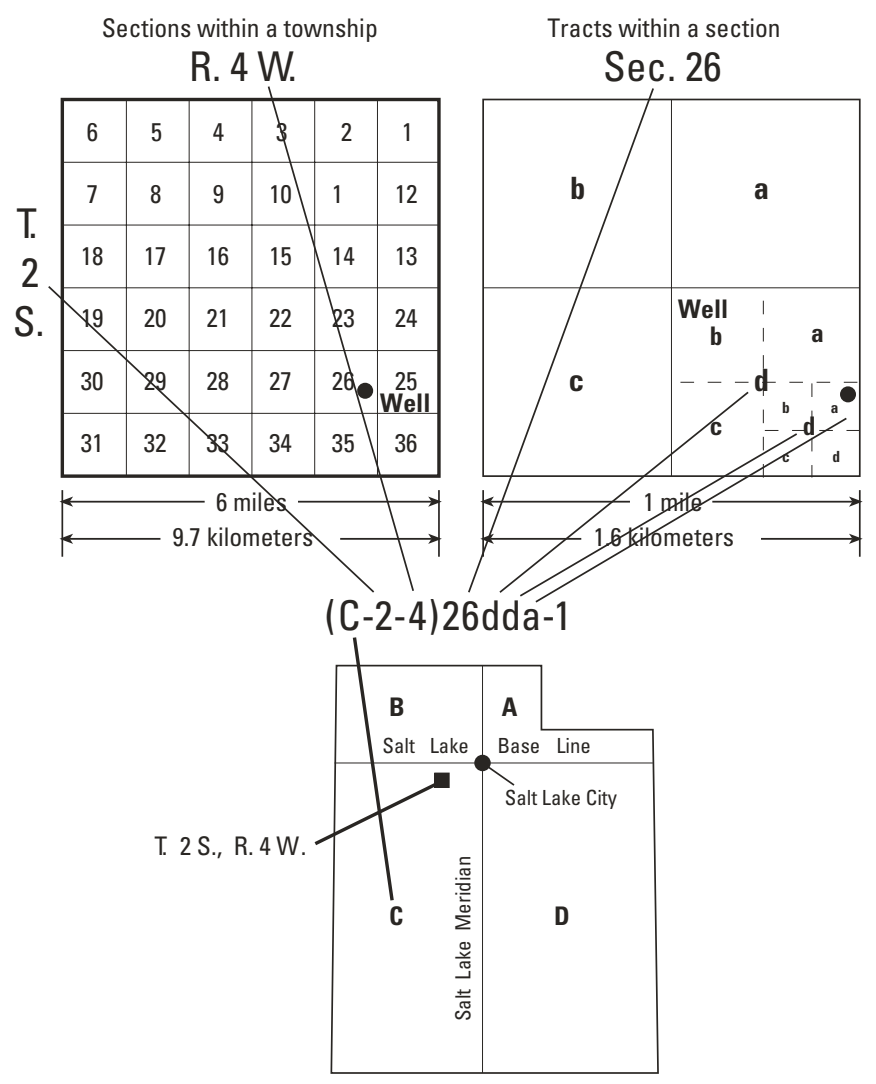

The system of numbering wells, springs, and other hydrologic-data sites in Utah is based on the cadastral land-survey system of the U.S. Government. The number, in addition to designating the site, describes its position in the land net. The land-survey system divides the State of Utah into four quadrants by the Salt Lake Base Line and the Salt Lake Meridian. These quadrants are designated by the uppercase letters A, B, C, and D, which indicate, respectively, the northeast, northwest, southwest, and southeast quadrants. Numbers that designate the township and range (in that order) follow the quadrant letter, and all three are enclosed in parentheses. The number after the parentheses indicates the section and is followed by three lowercase letters that indicate the quarter section, the quarter-quarter section, and the quarter-quarter-quarter section-generally 10 acres for regular sections ${ }^{1}$. The lowercase letters a, b, c, and d indicate, respectively, the northeast, northwest, southwest, and southeast quarters of each subdivision. The number after the letters is the serial number of the well or spring within the 10 -acre plot. The letter $\mathrm{S}$ preceding the serial number denotes a spring. Thus, (C-2-4)26dda-1 designates the first well constructed or visited in the NE 1/4 of the SE 1/4, of the SE 1/4, Sec. 26, T.2 S., R.4 W. The capital letter C indicates that the township is south of the Salt Lake Base Line and the range is west of the Salt Lake Meridian.

\footnotetext{
${ }^{1}$ Although the basic land unit, the section, is theoretically $1 \mathrm{mi}^{2}$, many sections are irregular. Such sections are subdivided into 10-acre tracts, generally beginning at the southeast corner, and the surplus or shortage is taken up in the tracts along the north and west sides of the section.
}

Figure 2. Numbering system for hydrologic-data sites in Utah. 
Table 1. Annual ground-water budget, Lake Point, Tooele County, Utah

[All flow amounts in acre-feet]

\begin{tabular}{lr}
\hline \multicolumn{1}{c}{ Budget component } & $\begin{array}{c}\text { Conceptual } \\
\text { flow } \\
\text { (rounded) }\end{array}$ \\
\hline \multicolumn{1}{c}{ Recharge } \\
\hline Precipitation & 3,800 \\
Irrigation & 400 \\
Inflow from southwest boundary & 1400 \\
Great Salt Lake & 0 \\
Total (rounded) & $\mathbf{4 , 6 0 0}$ \\
\hline \multicolumn{2}{c}{ Discharge } \\
\hline Factory Springs ${ }^{2}$ & 3,300 \\
Great Salt Lake & 1500 \\
Evapotranspiration & 500 \\
Wells, flowing wells, and small springs and drains & 400 \\
Outflow to west boundary & ${ }^{1} 40$ \\
Total (rounded) & $\mathbf{4 , 7 0 0}$ \\
\hline${ }^{1}$ Values simulated in steady-state model. \\
${ }^{2}$ Estimated amount of discharge to Factory Springs from the Lake Point \\
area. Total discharge to Factory Springs is about 6,000 acre-feet per year.
\end{tabular}

U.S. Geological Survey, written commun., 2001). A GISbased rainfall-runoff model that incorporates spatial estimates of precipitation, temperature, potential evapotranspiration, soil storage, and soil-infiltration capacity was used to determine the amount of precipitation that becomes either recharge or runoff (Flint, Flint, Hevesi, Blainey, Haltom, and Curtis, U.S. Geological Survey, written commun., 2001). Streamflow records were analyzed to determine mean annual streamflow, which was subtracted from the recharge plus runoff amount to determine recharge. During average precipitation conditions, negligible recharge occurs throughout most of the valley, which receives less than 13 in. of precipitation annually (fig. 3 ). The precipitation-runoff model for Tooele Valley is being refined and recharge estimates may change from those presented in this report; the change in Lake Point is not expected to be significant.

Recharge from irrigation is less than 10 percent of the recharge in Lake Point (table 1). For this study, it was assumed that recharge from irrigation has not changed from the longterm average of 25 percent of applied irrigation water (Lambert and Stolp, 1999, p. 15).

The Lake Point area is not hydrologically separated from the rest of Tooele Valley. Subsurface flow occurs across the southern and western boundaries for a net inflow of 400 acre$\mathrm{ft} / \mathrm{yr}$. Most inflow occurs within about $1.5 \mathrm{mi}$ south of Factory Springs. The amount of subsurface inflow was determined by using the regional model under development; an independently determined conceptual amount was not estimated.

\section{Discharge}

Discharge to Factory Springs is the largest component of discharge in Lake Point (table 1). The regional model of
Tooele Valley was adjusted to match the conceptually estimated discharge of 6,400 acre-ft/yr to Factory Springs (Lambert and Stolp, 1999, table 5) and was used to determine the portion of discharge to Factory Springs from the Lake Point area. Discharge to Great Salt Lake, evapotranspiration, and wells composes less than 25 percent of the discharge in the Lake Point area. Discharge to Great Salt Lake was estimated by using the regional numerical ground-water flow model. The simulated amount of 500 acre-ft/yr is reasonable given the estimated discharge to Great Salt Lake from all of Tooele Valley of 2,000 to 3,000 acre-ft/yr (Lambert and Stolp, 1999, table 6). The amount of domestic withdrawal in Lake Point was estimated on the basis of housing density. The estimated 170 houses in non-flowing well areas were estimated to withdraw about 170 acre-ft/yr of ground water; the estimated 50 houses in flowing well areas were estimated to use about 50 acre-ft/yr of ground water. One public-supply well discharged about 90 acre-ft/yr in 2002 (Oquirrh Mountain Water Company, oral commun., 2005). Discharge to non-domestic flowing wells, small springs, and drains was estimated to be 90 acre-ft/yr on the basis of visual observations and unpublished discharge records of the USGS. The total discharge amount to wells, springs, and drains of $400 \mathrm{acre}-\mathrm{ft} / \mathrm{yr}$ is the same as that reported by Gates (1965, table 1), but more discharge is from pumped wells and less discharge is from uncontrolled flowing wells.

\section{Salt-Water Intrusion}

Even though ground water discharges to Great Salt Lake, dense salt water from the lake intrudes under the less-dense ground water and forms a salt-water wedge underneath the valley. This salt water is responsible for some of the high dissolved-solids concentration values measured in ground water in Lake Point. The shape of the wedge and the distance it intrudes into the valley is dependent upon the density of water in Great Salt Lake, the difference between the altitude of the ground-water level and the altitude of Great Salt Lake, and the amount of ground-water flow to the lake (Domenico and Schwartz, 1990, p. 232-235). For hydrostatic conditions (water not flowing from the valley to the lake), the depth to the salt-water interface is determined by the difference in density between ground water and Great Salt Lake water as shown by equation 1 and illustrated in figure 4:

$$
z=h f(p f /(p s-p f))
$$

where:

$$
\begin{aligned}
z= & \begin{array}{l}
\text { depth below altitude of Great Salt Lake to } \\
\text { interface, any consistent length unit; } \\
\text { ground-water level above altitude of Great Salt } \\
\text { Lake, any consistent length unit; }
\end{array} \\
p f= & 1.000 \mathrm{~kg} / \mathrm{L}, \text { density of ground water; and } \\
p s= & 1.083 \mathrm{~kg} / \mathrm{L}, \text { density of Great Salt Lake water on } \\
& \text { May } 14,2002 \text { (Wilberg and others, 2003). }
\end{aligned}
$$

Therefore, $z=12 h f$. 


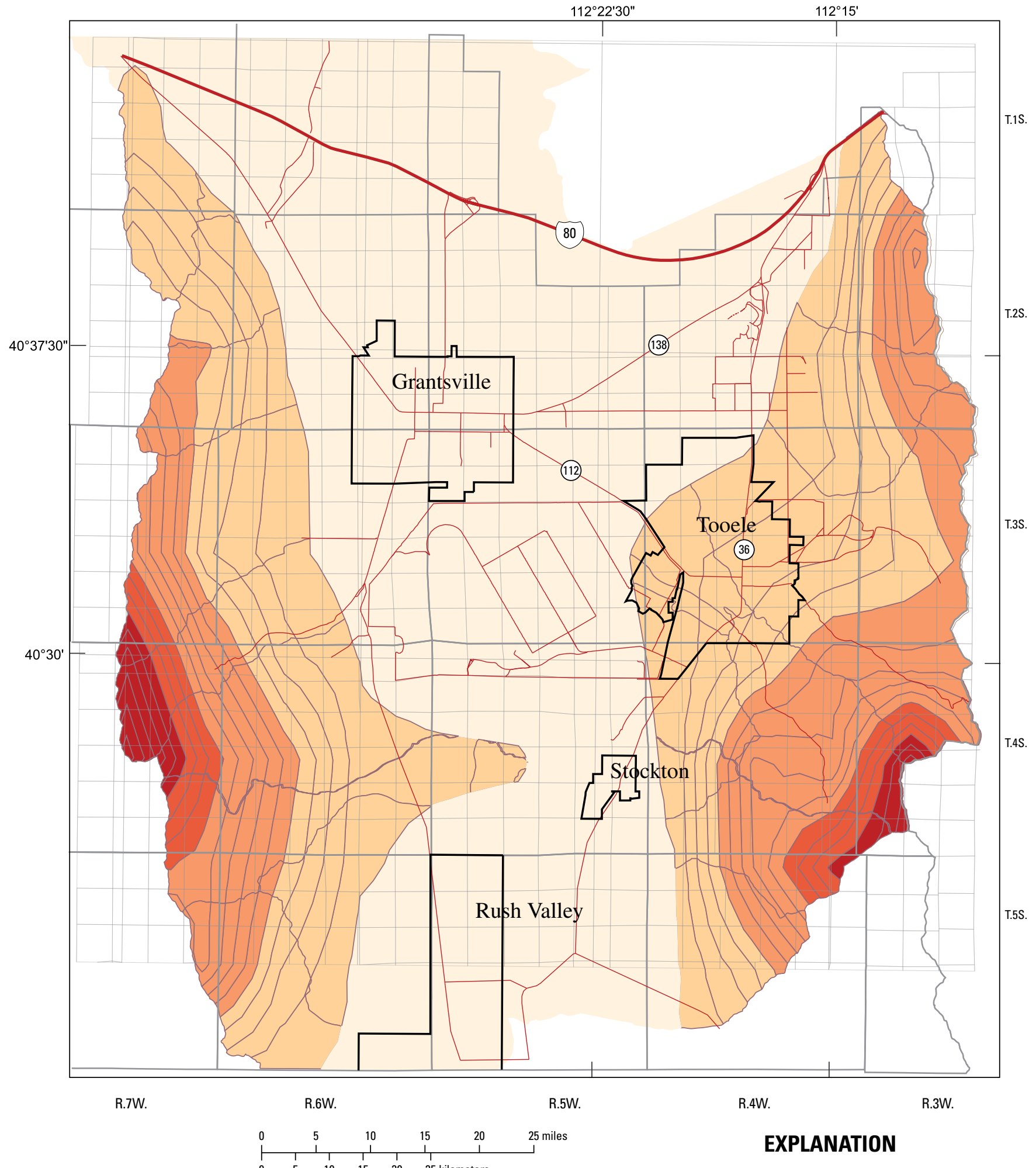

Average annual precipitation, in feet (Modified from Prism Group, Oregon State University, 2003)

0.917 to 1.083

1.083 to 1.750

1.750 to 2.583

2.583 to 3.750

3.750 to 4.083

Figure 3. Average annual precipitation for Tooele Valley and northern Rush Valley, Tooele County, Utah, 1971-2000. 


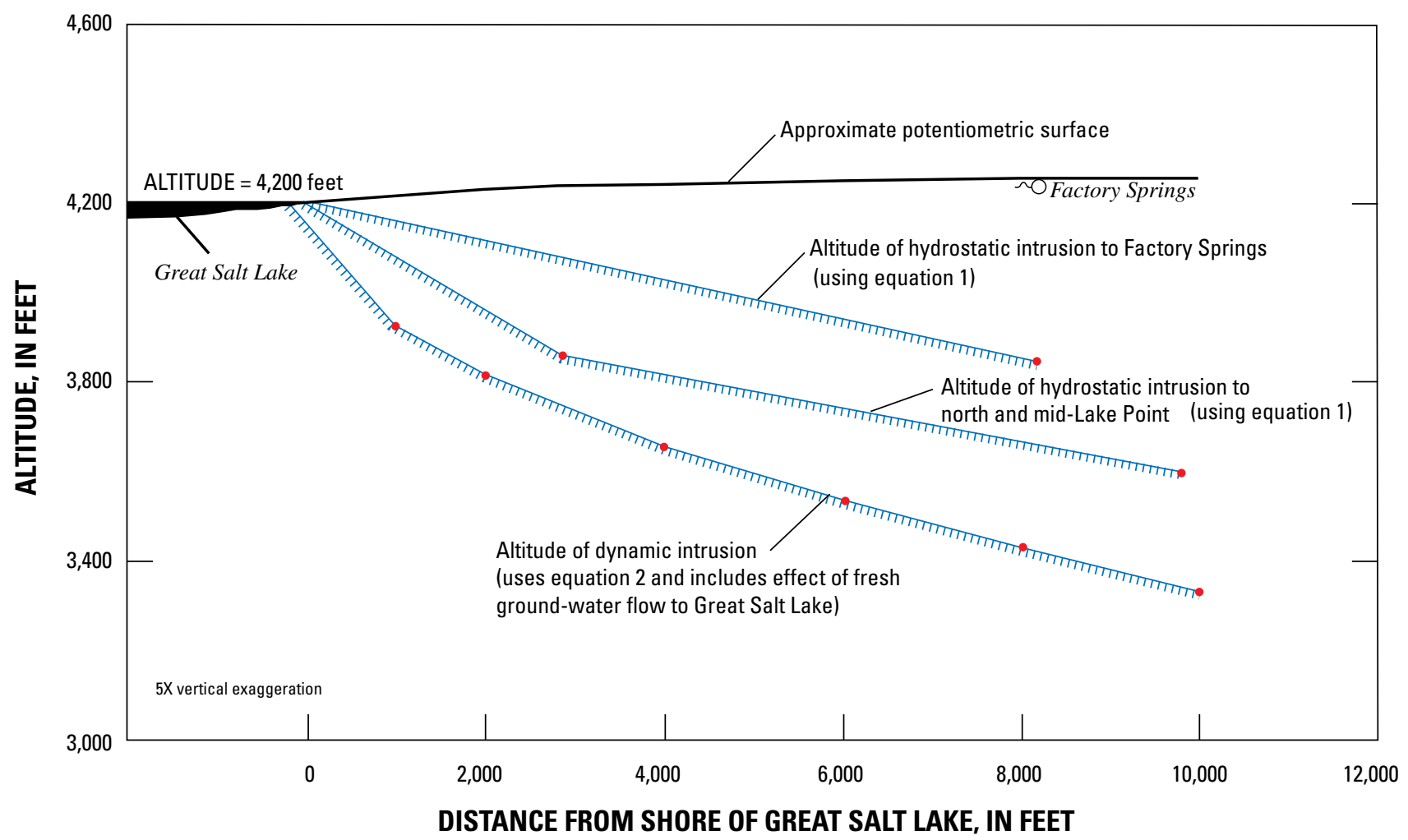

Figure 4. Generalized pattern of salt-water intrusion from Great Salt Lake, Lake Point, Tooele County, Utah.

A ground-water level of $50 \mathrm{ft}$ above lake level corresponds to $600 \mathrm{ft}$ of fresh water below lake level under the valley. In typical coastal ground-water flow systems, $z=40 h f$ and a ground-water level of $50 \mathrm{ft}$ above sea level corresponds to 2,000 ft of freshwater below sea level. The high density of Great Salt Lake water causes greater salt-water intrusion than in typical coastal systems. In most ground-water systems, equation 1 underestimates the depth to the salt-water interface because water flowing to the lake violates the assumptions of hydrostatic conditions used in the solution (Freeze and Cherry, 1979, p. 376). A solution including flow to the lake is described by Glover (1964, p. C32- C35) in which the depth to the intrusion is proportional to the amount of fresh-water flow into the lake and inversely proportional to hydraulic conductivity as shown by equation 2 . The interface calculated by equation 2 is lower than the interface calculated by equation 1 (fig. 4).

$$
y^{2}-2 q x / \gamma K-q^{2} / \gamma^{2} K^{2}=0
$$

where:
$y=$ the distance measured horizontally landward from the shoreline, in $\mathrm{ft}$;
$x=$ the distance measured vertically downward from the altitude of Great Salt Lake, in $\mathrm{ft}$;
$q=3.8 \mathrm{ft}^{2} / \mathrm{d}$, the fresh-water flow per unit length of

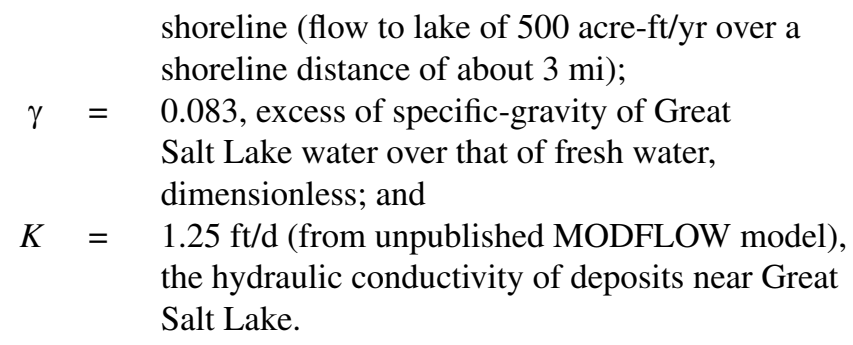

Equations 1 and 2 are estimates of salt-water intrusion because the flow paths are not perpendicular to Great Salt Lake. Much of the flow in Lake Point is to Factory Springs; some flow is west to Tooele Valley between Factory Springs and Great Salt Lake. The above equations also assume a sharp boundary between ground water and salt water, and do not account for mixing, dispersion, and diffusion that occur near the salt-water interface. The presence of Factory Springs possibly causes more salt-water intrusion in the Lake Point area than would occur without the springs. Ground-water discharge to Factory Springs is not available to discharge to Great Salt Lake and water levels are lower both because of the discharge and because the low altitude of Factory Springs controls ground-water altitude in that area. 


\section{Simulation of Ground-Water Flow}

A steady-state numerical ground-water flow model being developed for Tooele Valley was used to simulate the groundwater system in the Lake Point area. The model is modified from a previous model of Tooele Valley (Lambert and Stolp, 1999). Changes to the previous model were made incorporating the surrounding consolidated rock and the northern part of Rush Valley, modifying the amount and distribution of recharge from consolidated rock to the basin fill, modifying discharge to flowing wells and evapotranspiration, and modifying hydrologic properties of consolidated rock and basin fill to better match water levels not available during calibration of the previous model. In addition to these changes, development of the model included compilation and examination of waterlevel data and estimation of ground-water withdrawal.

Construction of the ground-water flow model was accomplished by discretization of the hydrologic properties of the ground-water system; establishment of model boundaries that best represent conceptual hydrologic boundaries; estimation of recharge rates and ground-water withdrawal rates; and assignment of model parameters to recharge, discharge, and hydrologic properties. The Tooele Valley model uses MODFLOW-2000, a three-dimensional, finite-difference, groundwater flow model (Harbaugh and others, 2000; and Hill and others, 2000).

The ground-water flow model described in this report uses parameters (Harbaugh and others, 2000, p. 4) to define much of the input data. A parameter is a single value that is given a name and determines the value of a variable in the finite-difference ground-water flow equation at one or more model cells. When parameters are used, the data value for a cell is calculated as the product of the parameter value, which might apply to many cells, and a cell multiplier, which applies only to that cell (Harbaugh and others, 2000, p. 13). Sensitivity analysis (Hill and others, 2000, p. 98) was used to guide model construction and calibration.

\section{Discretization}

Areally, the model is discretized into a grid of rectangular cells; each cell has homogeneous properties. Active cells delineate boundaries of the simulated ground-water system and generally correspond with surface-water divides at the top of mountain ranges. Cell size is variable and most active cells in Lake Point range in size from about 25 to 35 acres (fig. 5).

Vertically, the model is composed of five layers as described by Lambert and Stolp (1999, p. 21) for the unconsolidated basin fill. The bottom of layer 5 was changed from being variable to be a constant altitude of $3,100 \mathrm{ft}$ to enable consolidated rock to be more easily incorporated in the model. Layer 1 simulates ground-water flow near ground surface in the valley and does not extend to the benches or consolidated rock (fig. 5). Layers 2 to 5 were extended into the consolidated rock. The previous model was changed to define the thickness of each layer as required by MODFLOW- 2000. The saturated thickness of layer 2 varies from 120 to $240 \mathrm{ft}$ in basin fill and from 35 to $470 \mathrm{ft}$ in consolidated rock in the Lake Point area. The thickness of layer 3 is $150 \mathrm{ft}$, the thickness of layer 4 is $300 \mathrm{ft}$, and the thickness of layer 5 varies from 397 to 1,850 $\mathrm{ft}$. The boundary between basin fill and consolidated rock is not explicitly defined in the model; the hydrologic properties of each cell are proportional to the thickness of fill and rock in each cell.

\section{Boundary Conditions}

The boundaries chosen for the model describe mathematically how the simulated ground-water system interacts with the surrounding hydrologic system. Mathematical boundaries used to represent hydrologic boundaries include no-flow boundaries, specified-flux boundaries, and head-dependent flux boundaries. These boundaries define the physical limits of the model and simulate recharge to and discharge from the ground-water system. No-flow boundaries are considered impermeable and no flow is simulated across them. Specifiedflux boundaries allow a specified rate of water through the cell and are used to simulate most recharge and some discharge in this model. Head-dependent flux boundaries simulate flow across the boundary proportional to the difference in heads across the boundary and are used to simulate some recharge and discharge in this model.

\section{No-flow Boundaries}

The surface-water divide at the top of the Oquirrh Mountains is considered a no-flow boundary. It is not known if the ground-water divide follows the surface-water divide, but east of Lake Point it is a reasonable assumption. The unconsolidated basin fill and consolidated rock below an altitude of $3,100 \mathrm{ft}$ is considered a no-flow boundary; most of the groundwater flow in the system probably occurs above this altitude.

\section{Recharge Boundaries}

Specified-flux boundaries are used to simulate all recharge, which is from irrigation and precipitation, into the highest active cell. Areal recharge from irrigation was not changed from the previous model (Lambert and Stolp, 1999, p. 29-31). Recharge on consolidated rock was previously simulated as inflow at the boundary of the unconsolidated basin fill (Lambert and Stolp, 1999, p. 27-28). The addition of consolidated rock to the model area allowed this recharge to be changed to areal recharge on the consolidated rock. Recharge was distributed as a portion of mean annual precipitation to match new estimates of recharge in each hydrologic unit (see "Recharge" section of this report). The 1971-2000 average annual precipitation (fig. 3) was used to estimate recharge. 


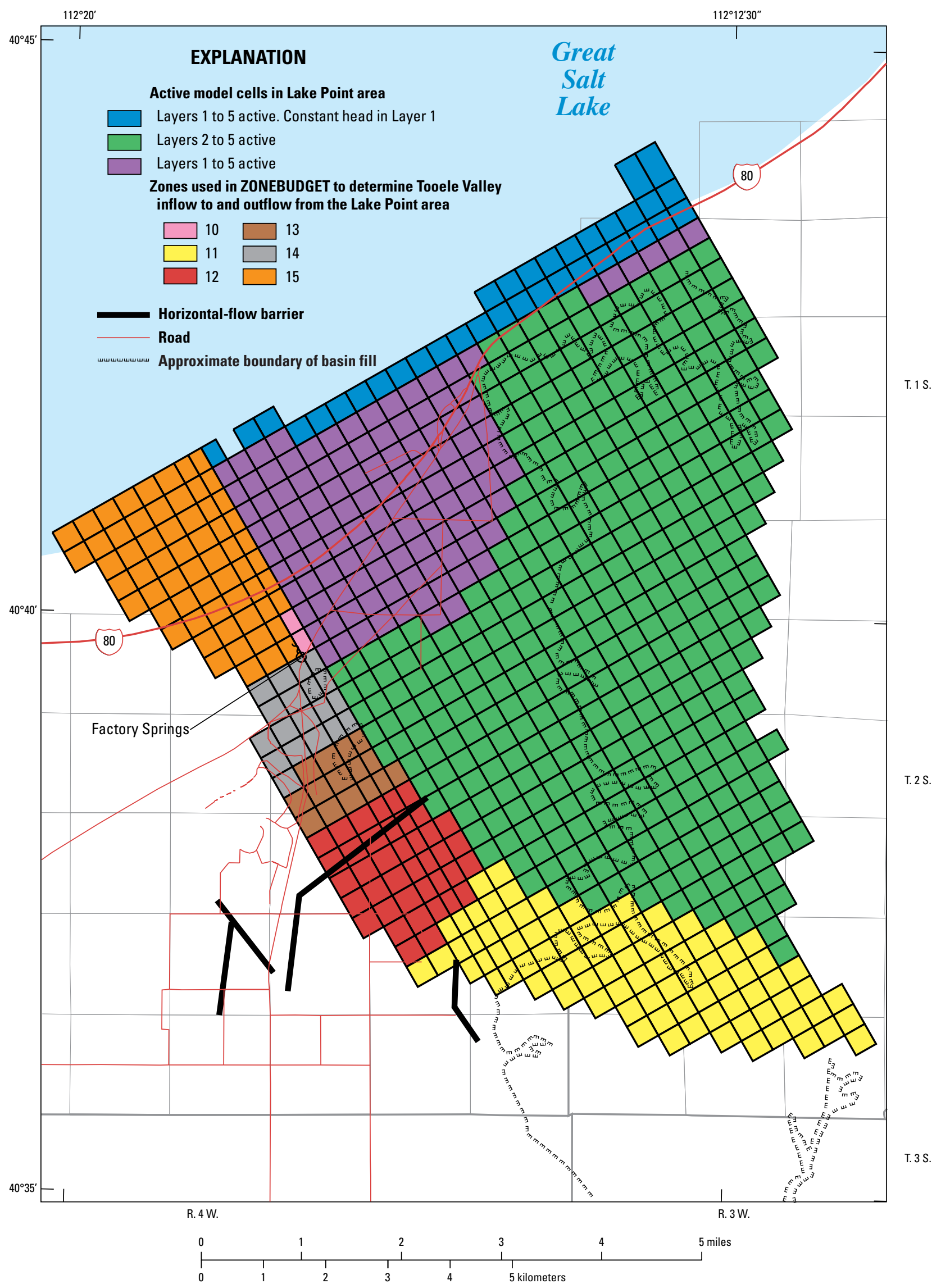

Figure 5. Model grid, simulated constant-head boundaries, area of model layer 1, budget zones, and horizontal-flow barriers in the ground-water flow model, Lake Point, Tooele County, Utah. 


\section{Discharge Boundaries}

Discharge to Factory Springs (fig. 5) is simulated as a head-dependent discharge boundary in layer 1 using the Drain Package (Harbaugh and others, 2000, p. 71). The drain elevation and conductance were modified from the previous model to more closely match more recent discharge data. The vertical conductance in all model layers below Factory Springs was assigned a value of $20 \mathrm{ft} / \mathrm{d}$ to allow flow from all layers to discharge at the cells representing the spring. The horizontal conductance at the spring cells was assigned values of $350 \mathrm{ft} / \mathrm{d}$ in the unconsolidated basin fill in layers 1, 2, 3, and 4 and 20 $\mathrm{ft} / \mathrm{d}$ in the consolidated rock in layers 4 and 5 .

Discharge to evapotranspiration is simulated as a headdependent flux boundary in layer 1 with the Evapotranspiration Package (Harbaugh and others, 2000, p. 73), and was modified slightly from the previous model (Lambert and Stolp, 1999, p. 32). The maximum evapotranspiration rate near springs was decreased because some of the plant demand is assumed to be met by spring discharge, not direct use of ground water.

Discharge to wells is simulated in layers 1 to 5 with the Well Package (Harbaugh and others, 2000, p. 69). The Well Package simulates a specified-flux boundary in each cell to which a well is assigned. On the basis of recorded well depths, domestic withdrawals in the Lake Point area were distributed in layers 1 and 2 (fig. 6). The areal distribution of domestic withdrawal was estimated based on housing density; each individual well was not simulated. The estimated 170 houses in the non-flowing well area were estimated to withdraw 1 acre$\mathrm{ft} / \mathrm{yr}$ each of ground water. Public-supply wells were assigned to the model cell and layers in which they occur.

Discharge to flowing wells is simulated from layer 2 by using the Drain Package (Harbaugh and others, 2000, p. 71). The land-surface altitude is used as the drain elevation; therefore, discharge will not occur if simulated water levels are below land surface. Flowing-well distribution was not changed from the previous model (Lambert and Stolp, 1999, fig. 14), but the conductance was decreased during calibration to more closely match the 50 acre-ft/yr of use based on estimated housing density in the flowing-well area. Very few flowing wells in the study area are allowed to discharge large amounts of water continuously.

\section{Hydraulic Conductivity}

The five-layer model represents saturated unconsolidated basin fill and consolidated rock. The top model layer simulates the unconfined conditions that typically exist near the top of the saturated zone in the middle of the valley and is inactive on the valley edges and mountains (fig. 5). Layer 2 represents unconfined conditions in the consolidated rock and edges of basin fill, and confined conditions where layer 1 is present. Layers 3, 4, and 5 simulate confined conditions that typically exist deeper in the saturated system. Although continuous clay layers are not evident in Tooele Valley, lenses of finegrained material confine water in the deeper basin fill. The hydrologic properties that control simulated water levels are horizontal and vertical hydraulic conductivity. The model was constructed to allow aquifer characteristics to vary areally by using parameters and multiplier and zone arrays (Harbaugh and others, 2000, p. 15).

Horizontal hydraulic conductivity in the unconsolidated basin fill was assumed to decrease as the percentage of coarse material in the unconsolidated basin fill decreases (Lambert and Stolp, 1999, p. 11). Because the coarse materials are not all the same, MODFLOW-2000 zones were used to delineate areas of differing hydraulic conductivity $(f i g .7 a)$. It is assumed that all fine material in the unconsolidated basin fill has a hydraulic conductivity of $1 \mathrm{ft} / \mathrm{d}$ (Lambert and Stolp, 1999, p. 40). All model layers were assumed to have the same distribution of hydraulic conductivity of the coarse and fine deposits. MODFLOW-2000 zones also were used to delineate areas of differing hydraulic conductivity of consolidated rock (fig. 7 d). The hydraulic conductivity of each cell is a function of the conductivity and thickness of coarse material, fine material, and consolidated rock in each cell. Vertical hydraulic conductivity was defined in the model with parameters and a zone array (Harbaugh and others, 2000, p. 60).

\section{Horizontal-Flow Barriers}

Observed water levels in many parts of the valley indicate distinct variability in the hydraulic gradient. Areas where the gradient steepens abruptly could not be simulated using only changes in hydraulic conductivity. Flow barriers were simulated with the Horizontal-Flow Barrier Package (Harbaugh and others, 2000, p. 63) to inhibit water movement in areas of steep gradients. This package allows hydraulic conductivity and flow between cells to be decreased without affecting the hydraulic conductivity of the adjacent cells. Several barriers are simulated just south of the Lake Point area (fig. 5). The geologic reason for these apparent ground-water flow impediments has not been determined.

\section{Calibration}

The purpose of calibration is to develop a model that reasonably represents ground-water recharge, movement, and discharge, and reasonably matches measured water levels. The differences between simulated and measured water levels and flows should be acceptable for the intended use of the model. This model has been developed to simulate general groundwater flow throughout Tooele Valley with added emphasis on the Lake Point area. It should adequately represent areal responses to changes in ground-water withdrawals, but has not been developed to simulate cell-by-cell effects. The model is a simplified representation of the ground-water system and does not completely represent local heterogeneity in aquifer properties, recharge, or discharge. Cell-by-cell flow rates are not 


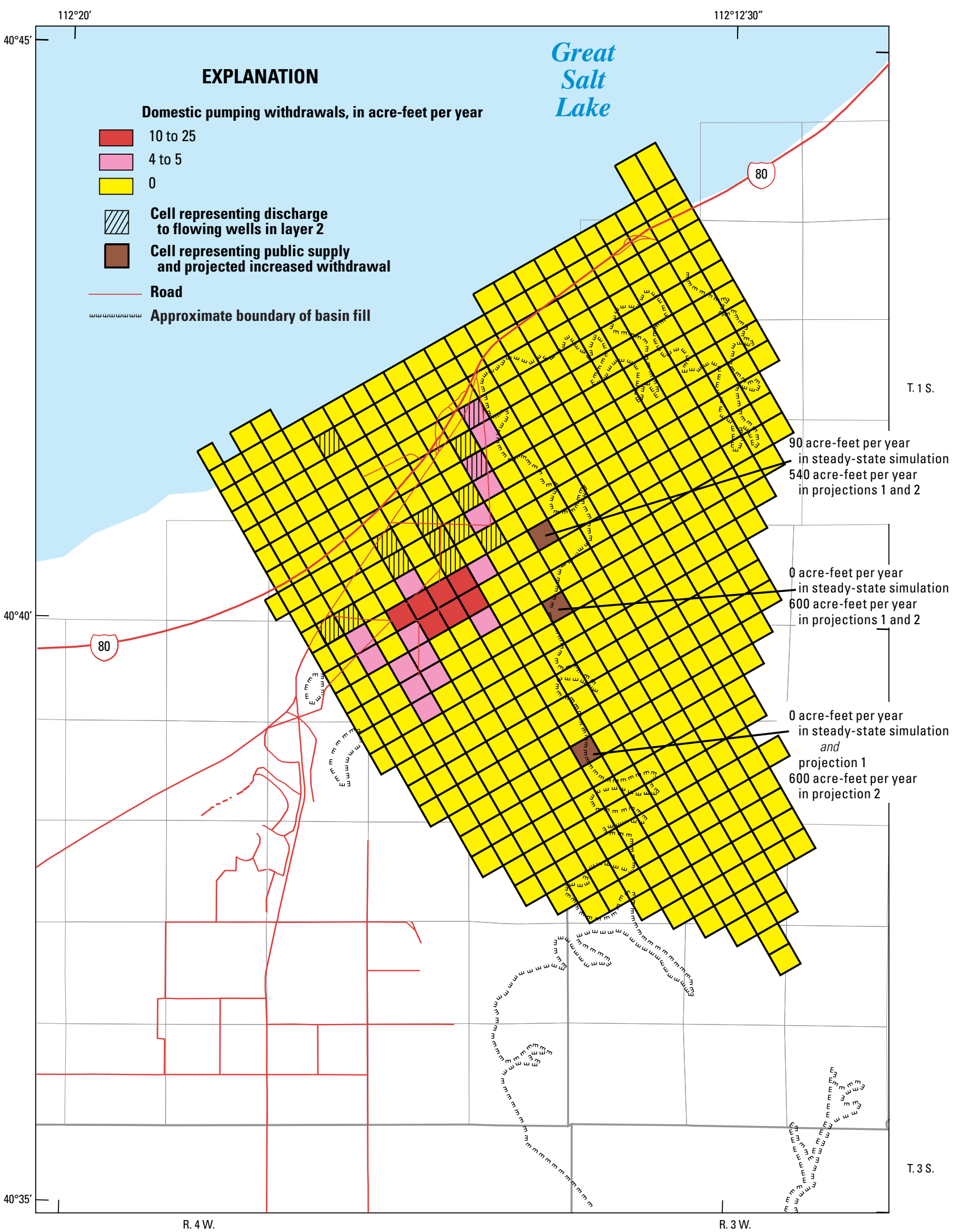

Figure 6. Distribution of withdrawal from wells simulated in the ground-water flow model, Lake Point, Tooele County, Utah. 


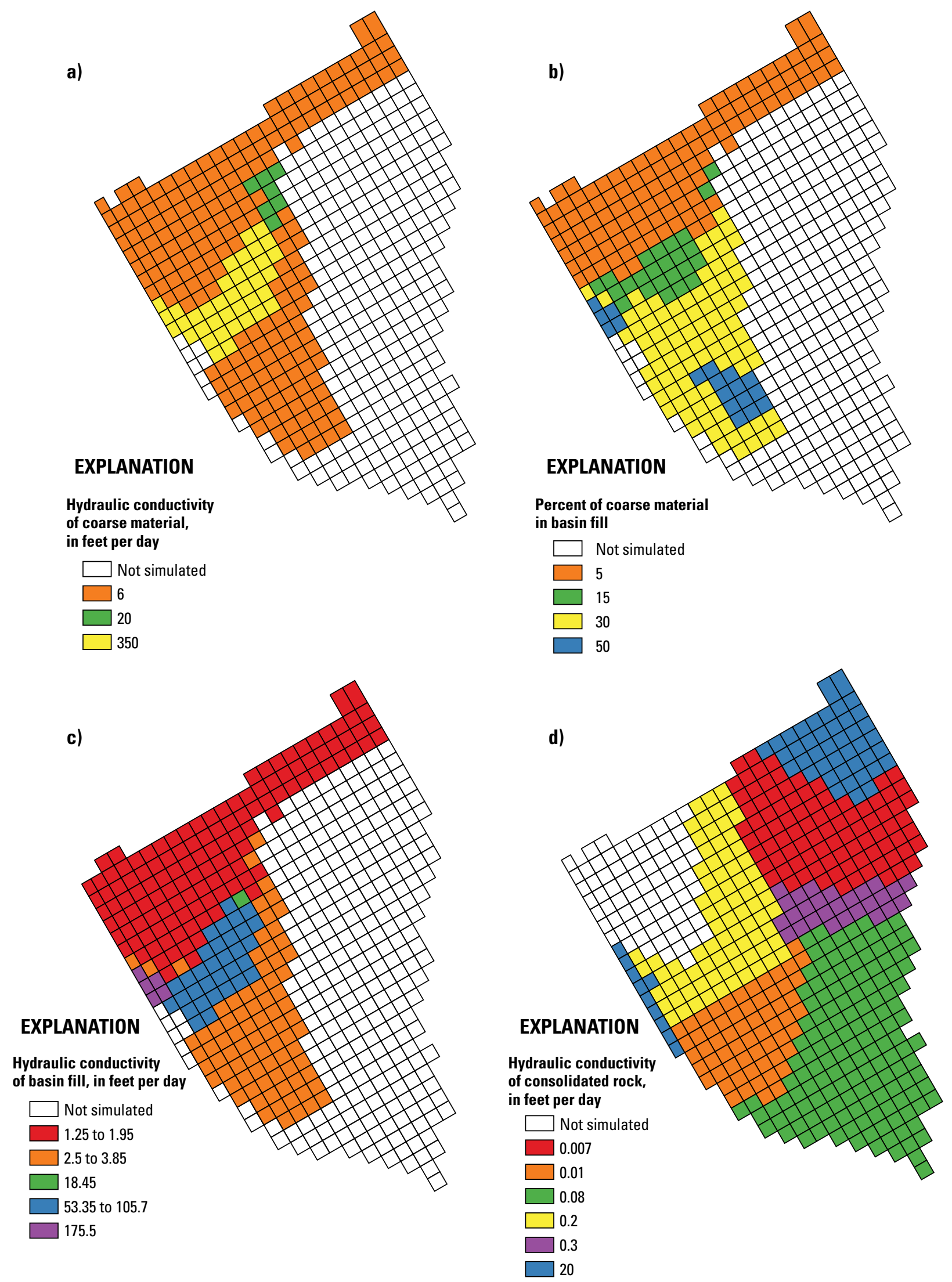

Figure 7. (a) Hydraulic conductivity of coarse material in unconsolidated basin fill, (b) percent of coarse material in basin fill, (c) simulated hydraulic conductivity of unconsolidated basin fill, and (d) simulated hydraulic conductivity of consolidated rock in the ground-water flow models, Lake Point, Tooele County, Utah. 
considered to be an accurate representation of ground-water movement on a small scale. In general, ground-water flow models can be considered more representative of the groundwater system in areas where simulated flow and water-level data more closely match measured values. Few data are available for water levels in consolidated rock or at the boundary of consolidated rock and unconsolidated basin fill; thus it is not known if the model is an accurate representation of the system in these areas. The highly spatially variable measured water levels in these areas indicate a geologic complexity that may not be simulated correctly.

To determine the value and distribution of hydraulic conductivity and the conductance of drains and horizontalflow barriers, the simulated properties were adjusted to cause simulated water levels and discharge to more closely match measured steady-state conditions. Recharge and evapotranspiration were adjusted to approximate the conceptual budget, but were not adjusted to aid calibration. Ground-water levels measured in March 1969 and March 2002, and a modified conceptual ground-water budget for the steady-state period (Lambert and Stolp, 1999, table 6), were compared to simulated values. Water levels from March 2002 were used in the Lake Point area because earlier levels were not available. Only a small amount of ground-water development has occurred in the Lake Point area and the 2002 levels are probably similar to steady-state levels. Water levels from other years were used in a few areas if levels during 1969 or 2002 were not available.

MODFLOW-2000 allows measured water levels to be input as observations; MODFLOW-2000 calculates simulated values of water levels at the location of input observations, then calculates and prints the difference between observation values and simulated values, weighted residuals, and other statistical measures of model fit. Forty-four water levels in Lake Point were used as observations for the steady-state simulation. Throughout this text, "measured" water level refers to field measurement of water levels and "observed" water level or "observation" refers to the value input as an observation in MODFLOW-2000.

\section{Parameter Sensitivity and Adjustment}

During model calibration, parameters were adjusted to minimize the sum of squared errors between simulated and observed water levels, while still simulating approximate known or estimated water-budget components. The sensitivity of observations to parameters was used to aid model calibration. Composite scaled sensitivities can be used to evaluate whether available observations provide adequate information to estimate each parameter and can provide an overall view of the parameters to which the observations are most sensitive (Hill and others, 2000, p. 96). Simulated values at observation locations in Lake Point are more sensitive to recharge from precipitation and hydraulic conductivity of consolidated rock than to any other model parameters. Because of the high sensitivity, more effort was made to conceptually define recharge and to numerically refine hydraulic conductivity than other calibration parameters. Some parameters were refined to achieve a better match between simulated water levels and observed water levels in local areas, even though the composite scaled sensitivities are not high.

\section{Comparison to Observations}

The steady-state ground-water flow model adequately simulates water levels measured in Lake Point in 1969 and 2002, measured discharge at Factory Springs, and estimated discharge to evapotranspiration and flowing wells. Simulated water levels are within $5 \mathrm{ft}$ of most observed water levels and within 6 to $14 \mathrm{ft}$ of the remaining observed levels in Lake Point (fig. 8). Simulated water levels at the north end of the Oquirrh Mountains are greater than $30 \mathrm{ft}$ different from observed levels, indicating that this geologically complex area may not be simulated accurately. Ground-water flow direction indicated by contours of simulated water-level altitude in model layer 2 ( fig. 8) is similar to ground-water flow direction indicated by contours of measured water-level altitude (Kenney and others, 2006). Similarities between simulated and observed water levels indicate that simulated recharge, discharge, and distribution of hydrologic properties adequately represent the ground-water system.

\section{Model Limitations and Need for Additional Data}

The hydrologic properties simulated in this model are reasonable approximations of the actual hydrologic properties if the simulated ground-water budget is correct. This groundwater flow model, however, should not be considered unique. Other combinations of recharge, discharge, and aquifer properties may yield a similar or improved match to measured water levels. Flow measurements (such as discharge to streams or springs) are typically more useful than water-level measurements in obtaining a unique simulation, and several flow measurements are available in the regional model. Better estimates of evapotranspiration from ground water could be useful calibration data. Better estimates of discharge to springs, flowing wells, and evapotranspiration also conceptually limit the variability of the recharge estimate. The conceptual rate of ground-water withdrawal is considered accurate and was not varied in the model. The final values of all model parameters are based on that withdrawal rate. Calibrating to a different rate of ground-water withdrawal could change the final values of the calibration parameters.

The ground-water model does not accurately represent the extreme heterogeneity typical of consolidated rock. The hydraulic conductivity simulated represents the average conductivity of the rock needed to move water through the system, and does not account for fracture flow. Because of this, simulated drawdown at pumping wells in rock may exceed measured drawdown substantially. Many production wells are completed only in zones observed during drilling to yield water and may represent maximum hydraulic conductivity. 


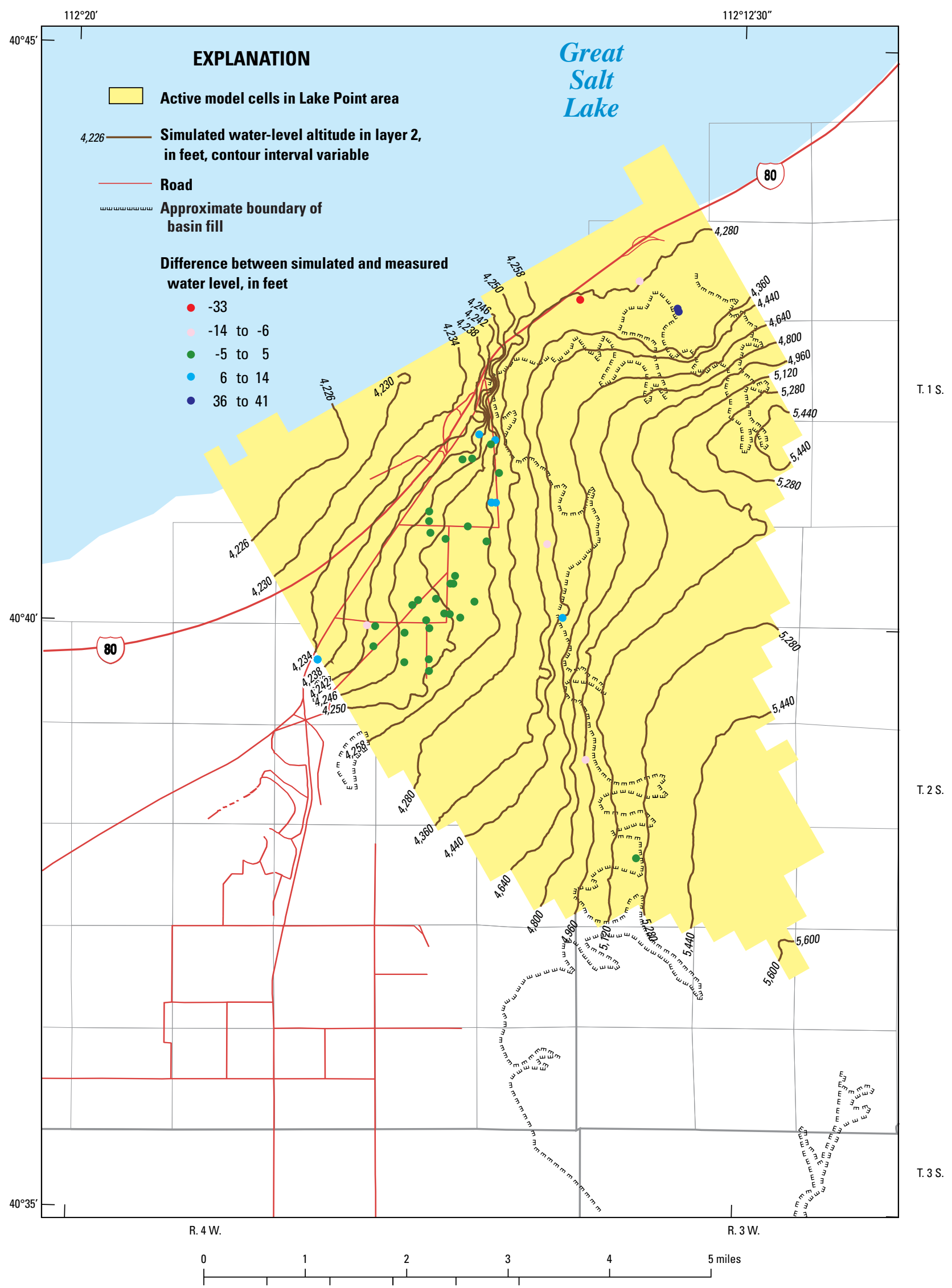

Figure 8. Ground-water altitude simulated in layer 2 of the steady-state ground-water flow model, and difference between simulated ground-water altitude and selected ground-water altitudes measured in March 1969 and March 2002, Lake Point, Tooele County, Utah. 
The composite scaled sensitivities indicate that water levels in most of the Lake Point area provide more data about recharge parameters than about any other model parameters. Future efforts to refine the estimate of location and amount of recharge may improve model fit and refine the conceptual understanding of the ground-water system. If recharge is determined to be substantially different than that used in the construction of this model, then simulated aquifer characteristics and other model parameters may not be realistic estimates of actual hydrologic properties.

\section{Model Projections}

The ground-water flow model was used to estimate possible effects on water levels and spring discharge caused by increased withdrawal from wells completed in the consolidated rock on the east side of Lake Point. The first projection simulated 1,050 acre-ft/yr increased withdrawal. The second projection simulated 1,650 acre-ft/yr increased withdrawal. The projections were made as steady-state simulations and do not indicate the time required for the changes to occur. The computer program ZONEBUDGET (Harbaugh, 1990) was used to determine the simulated Lake Point ground-water budget for the steady-state model and both projections (table 2).

Model projections should not be used to predict actual water levels at some future date, but can give general ideas about water-level declines and decreases in ground-water discharge likely to occur throughout the area. Because few data are available in the consolidated rock, the projected water levels in consolidated rock are uncertain. The more the projected stresses vary from stresses used during the calibration period, the more likely simulated water-level declines may not accurately represent actual water-level declines. The groundwater system could react in ways that are not simulated in these projections.

Simulated water-level declines in the projection simulations are referred to as drawdown, which is the change in water level from the steady-state simulation. Simulated decrease in discharge to springs, flowing wells, evapotranspiration, and Great Salt Lake is the decrease from the discharge simulated in the steady-state model.

The maximum projected drawdown in projection 1 of about $340 \mathrm{ft}$ occurs in layer 3 at the pumping well (C-24)1ddc-1 (fig. 9). Layer 2 becomes dry at that location and at one cell near pumping well (C-2-4)1abd-1. Drawdown in most of the developed part of Lake Point ranges from 2 to 6 $\mathrm{ft}$. Drawdown in the consolidated rock east of the increased withdrawal exceeds $30 \mathrm{ft}$ over a large area. Discharge to Factory Springs, flowing wells, evapotranspiration, and Great Salt Lake is decreased by about 700 acre-ft/yr (17 percent).

The maximum projected drawdown in projection 2 (a $1,650 \mathrm{acre}-\mathrm{ft} / \mathrm{yr}$ increase in withdrawal) of about $550 \mathrm{ft}$ occurs in layer 4 at the pumping well (C-2-3)18bbc-1 (fig. 10). Layers 2 and 3 become dry at that location. Layer 2 becomes dry at several cells around the three pumping wells. Drawdown in most of the developed

[All flow in acre-feet per year; zone numbers refer to figure 5]

\begin{tabular}{lrrr}
\hline \multicolumn{1}{c}{ Budget component } & Steady state & Projection 1 & Projection 2 \\
\hline & Inflow & & \\
\hline Recharge from precipitation and irrigation & 4,300 & 4,300 & 4,300 \\
Inflow from zone 11 & 0 & 0 & 0 \\
Inflow from zone 12 & 0 & 0 & 0 \\
Inflow from zone 13 & 430 & 450 & 480 \\
Inflow from zone 14 & 260 & 490 & 600 \\
Inflow from zone 15 & 0 & 0 & 0 \\
Great Salt Lake & 0 & 0 & 0 \\
Total (rounded) & $\mathbf{5 , 0 0 0}$ & $\mathbf{5 , 2 0 0}$ & $\mathbf{5 , 4 0 0}$ \\
\hline \multicolumn{1}{c}{ Outflow } & & \\
\hline Factory Springs from Lake Point & 3,320 & 2,710 & 2,410 \\
Great Salt Lake & 540 & 530 & 520 \\
Evapotranspiration & 360 & 320 & 300 \\
Pumping wells & 260 & 1,310 & 1,910 \\
Drains and flowing wells & 170 & 80 & 60 \\
Outflow to zone 11 & 220 & 200 & 90 \\
Outflow to zone 12 & 50 & 50 & 40 \\
Outflow to zone 13 & 0 & 0 & 0 \\
Outflow to zone 14 & 0 & 0 & 0 \\
Outflow to zone 15 & 40 & 30 & 20 \\
Total (rounded) & $\mathbf{5 , 0 0 0}$ & $\mathbf{5 , 2 0 0}$ & $\mathbf{5 , 4 0 0}$ \\
\hline \multicolumn{1}{c}{ Factory Springs, total } & 5,900 & 5,300 & 4,900 \\
Mill Pond & 4,700 & 4,600 & 4,500 \\
Rose Springs & 220 & 210 & 160 \\
\hline
\end{tabular}
part of Lake Point ranges from 2 to 10 $\mathrm{ft}$, but increases to more than 40 feet in the areas proposed for residential development south and east of Lake Point. Drawdown in the consolidated rock east of the increased withdrawal exceeds $80 \mathrm{ft}$ over an area encompassing most of the Oquirrh Mountains east of Lake Point. Discharge to Factory Springs, flowing wells, evapotranspiration, and Great Salt Lake is decreased by about 1,100 acre-ft/yr (25 percent).

Drawdown in the Oquirrh Mountains may be overestimated in the simulations because of the simulated no-flow boundary at the crest of the Oquirrh Mountains. It is possible that increased withdrawal in Lake Point could induce flow from the east side of the Oquirrh Mountains.

All water withdrawn from wells must be balanced by loss of storage in the ground-water system, decrease in natural discharge, and increase in recharge equal to the amount with- 


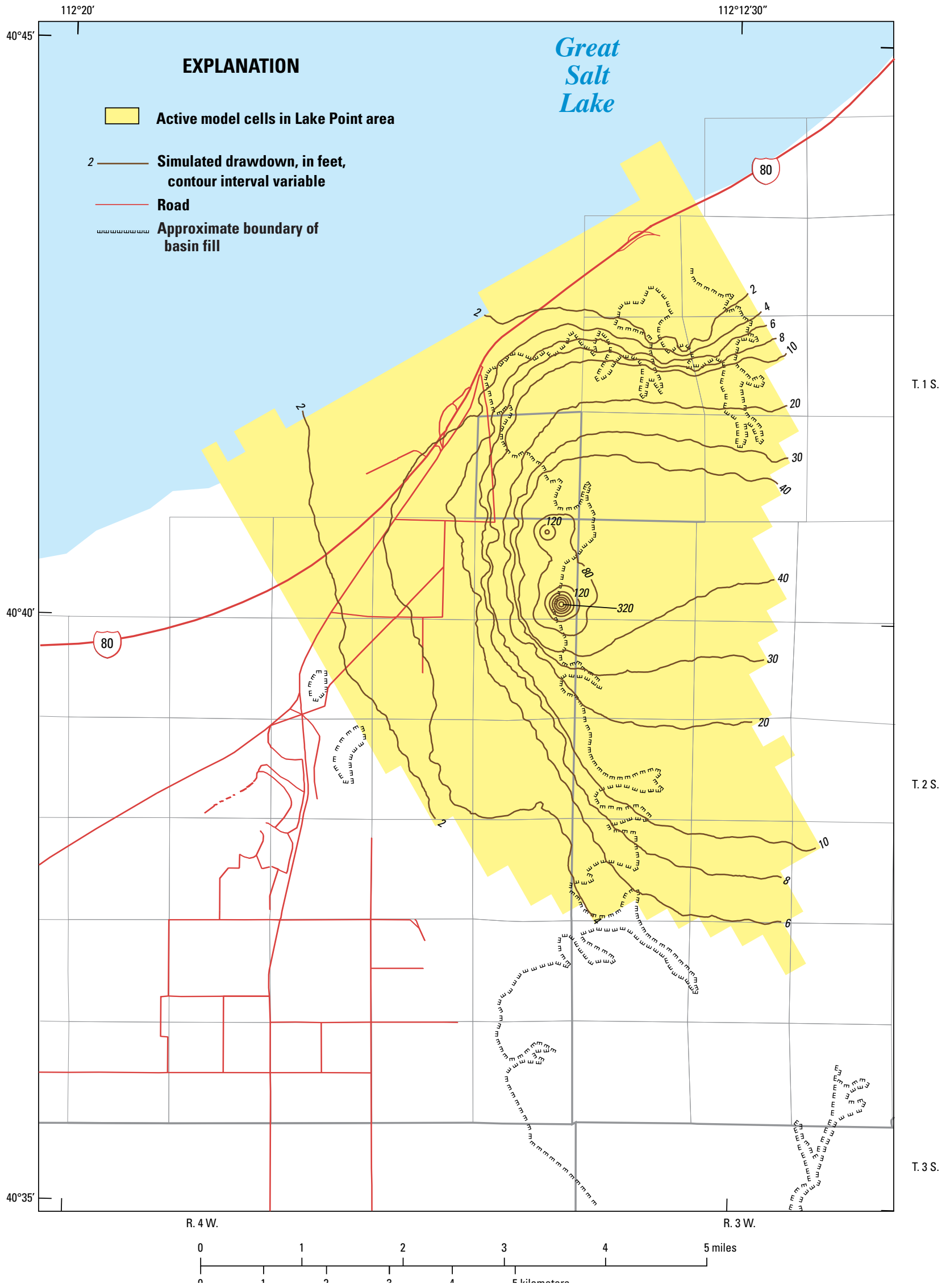

Figure 9. Simulated drawdown in model layer 3, projection 1 of the ground-water flow model, Lake Point area, Tooele County, Utah. 


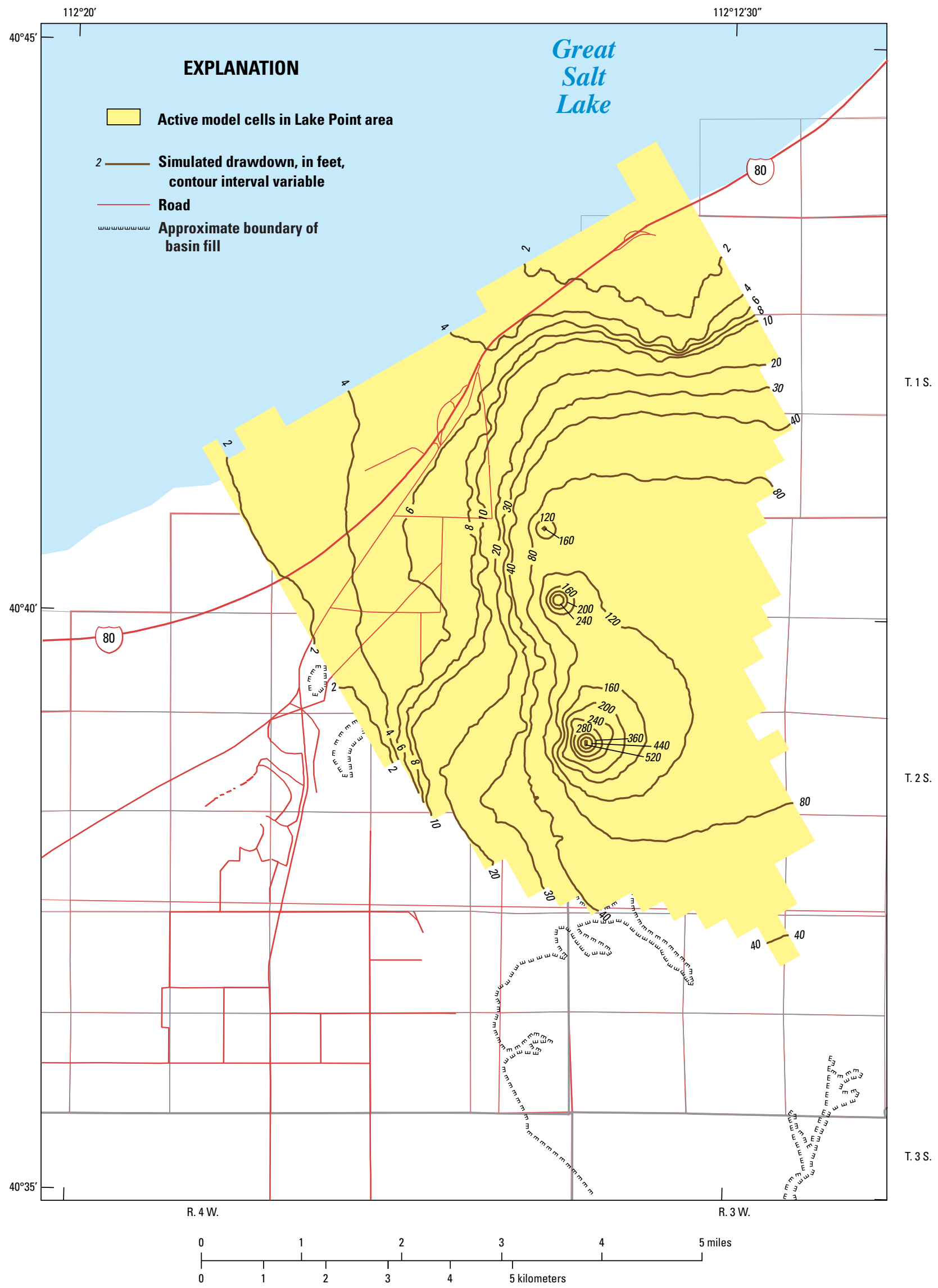

Figure 10. Simulated drawdown in model layer 4, projection 2 of the ground-water flow model, Lake Point area, Tooele County, Utah. 
drawn. The first effect, decrease in storage, continues to reduce water levels until natural discharge is decreased and recharge increased enough to allow the system to be in a new "steady-state." The projections simulate this new condition where recharge again equals discharge. Most of the new balance has been achieved by decreasing discharge from Factory Springs (fig. 11). About 25 percent of the new balance has been achieved because recharge has been captured by extending the zone of influence of the pumping wells to bring more flow into the area from outside of Lake Point. Decreases in evapotranspiration, discharge to flowing wells, flow to Great Salt Lake and flow out of Lake Point to the west account for about 20 percent of the change.

The simulated effects of increased withdrawal extend beyond the Lake Point area. The increase in inflow to the Lake Point area (fig. 11 and table 2) is not available to discharge to other locations in Tooele Valley. In addition to the decrease in discharge from Factory Springs directly from Lake Point, discharge from Factory Springs is also reduced because of decreased water levels in the regional model (table 2). Discharge from Mill Pond and Rose Springs southwest of the study area also decrease (table 2).

\section{Simulation of Variable-Density Ground- Water Flow}

In addition to decreasing water levels and discharge to Factory Springs and flowing wells, increasing withdrawals in Lake Point has the potential to increase salt-water intrusion from Great Salt Lake into the ground-water system. Numerical simulation of the ground-water system including variabledensity flow was used to estimate the current pattern of saltwater intrusion, the zone of mixing, and whether additional ground-water development in Lake Point will lower water levels enough to allow salt water to intrude farther. The USGS model SUTRA (Voss and Provost, 2002) simulates saturatedunsaturated, variable-density ground-water flow with solute or energy transport and was used to simulate the saturated flow system in the Lake Point area with variable-density flow.

The SUTRA model simulates only the Lake Point area and was used to simulate flow during steady-state conditions as represented in 2002, flow with increased withdrawals of
1,050 acre-ft/yr, and flow with increased withdrawals of 1,650 acre-ft/yr. The boundary conditions for the SUTRA model were derived from the regional MODFLOW-2000 model and imported to the Lake Point area SUTRA model. Areal recharge, hydraulic conductivity, and geometry of the Lake Point area do not change during the simulations. The calculations involved in SUTRA require finer vertical discretization than is required by MODFLOW-2000, and each MODFLOW2000 layer was subdivided into many SUTRA layers. The SUTRA finite-element mesh is vertically aligned and closely follows the boundaries of the active MODFLOW-2000 cells in the Lake Point area (fig. 12). The SUTRA mesh extends farther into Great Salt Lake than the MODFLOW-2000 grid to allow the salt-water interface to move under the lake. SUTRA allows for specified pressure and concentration at the Great Salt Lake boundary and determines the flow to the lake during solution.

Flow across the SUTRA model boundaries and discharge from the ground-water system change for each of three model simulations. The flow across the southern and western boundaries of the Lake Point model was determined by using the regional MODFLOW model and ZONEBUDGET (Harbaugh, 1990) and was input to SUTRA as specified inflow or outflow. Withdrawal from wells is simulated as a specified discharge. SUTRA does not simulate head-dependent boundaries; discharge at head-dependent boundaries such as springs, flowing wells, and evapotranspiration was determined in the regional MODFLOW model and input to the Lake Point SUTRA model as specified discharge.

The SUTRA simulations include only Great Salt Lake as a source of dissolved solids. Other sources, such as geologic or human sources are not simulated nor included in the concentrations calculated by SUTRA.

In addition to flow data, SUTRA requires the density of fresh water, dissolved-solids concentration of Great Salt Lake, the relation between concentration and density, dispersivity, diffusion, viscosity of water, and effective porosity of the consolidated rock and basin fill (table 3). SUTRA solves the flow equations using pressure, not head. The flow equation, therefore, is dependent on the density of the water and the force of gravity. The relations between density, gravity, and pressure are more conveniently defined using the International System (SI) of measurement, so the English units used in the modified

Table 3. Values of fluid and solid properties used in SUTRA simulations, Lake Point area, Tooele County, Utah

\begin{tabular}{lc}
\hline \multicolumn{1}{c}{ Property } & Value \\
\hline Density of ground water & 1,000 kilograms per cubic meter \\
Dissolved-solids concentration of Great Salt Lake water & 122 kilograms per cubic meter \\
Increase in density per unit change in dissolved-solids concentration & 680 kilograms per cubic meter \\
Longitudinal dispersivity & 400 meters \\
Transverse dispersivity & 10 meters \\
Diffusion of solute in water & $1 \times 10^{-9}$ square meters per second \\
Viscosity of water & 0.001124 kilograms per meter-second \\
Effective porosity & 0.1 \\
\hline
\end{tabular}



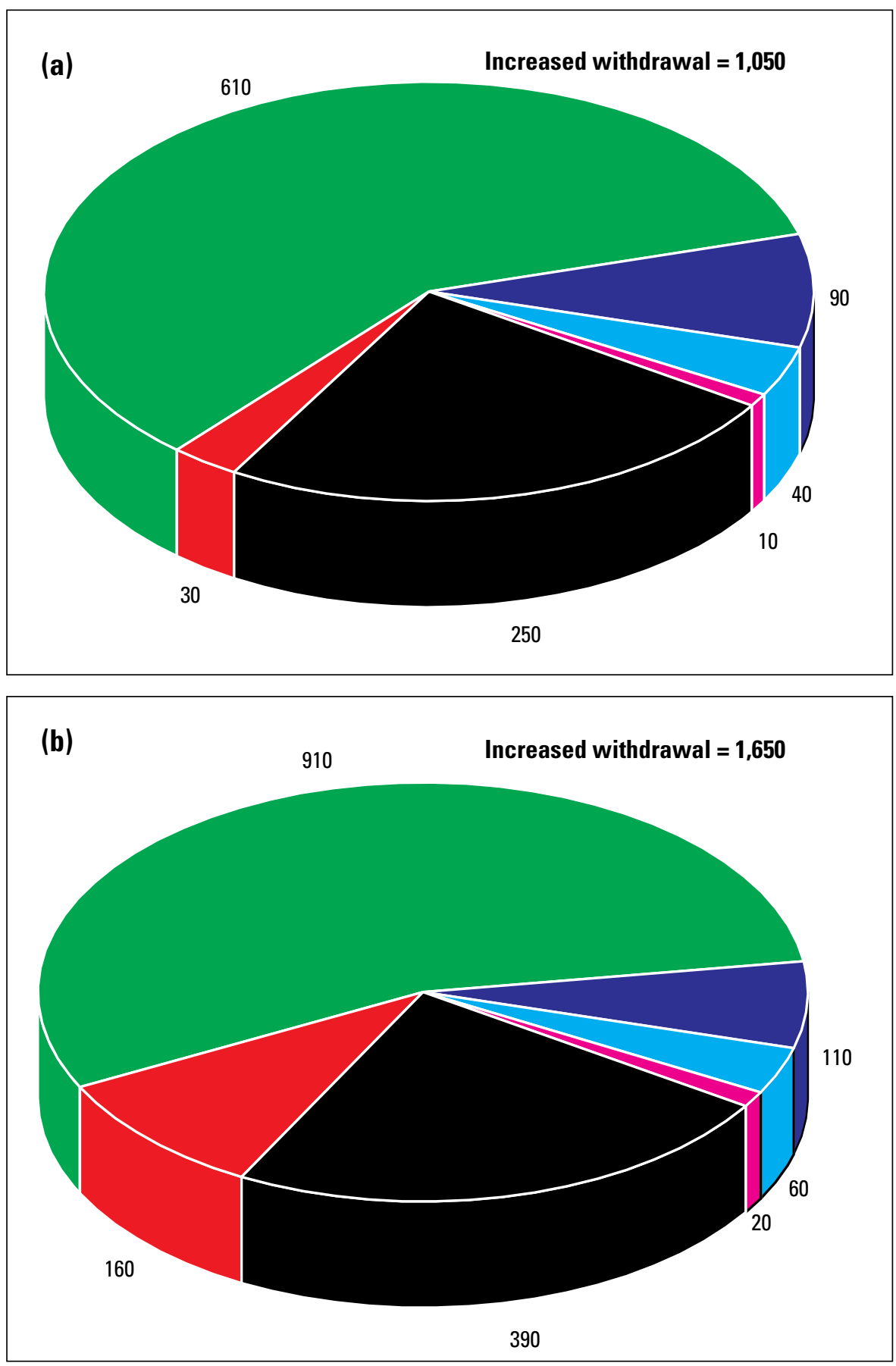

\section{EXPLANATION}

All amounts in acre-feet per year

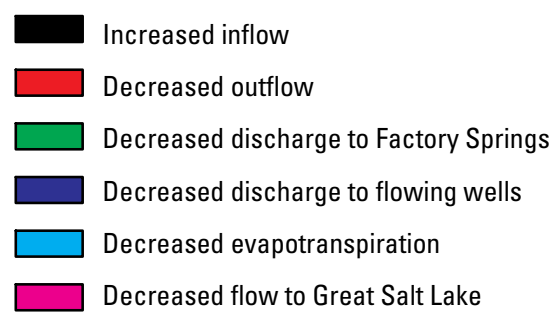

Figure 11. Simulated change in water-budget components to meet increased withdrawal for (a) projection 1 and (b) projection 2 of the ground-water flow model, Lake Point area, Tooele County, Utah. 


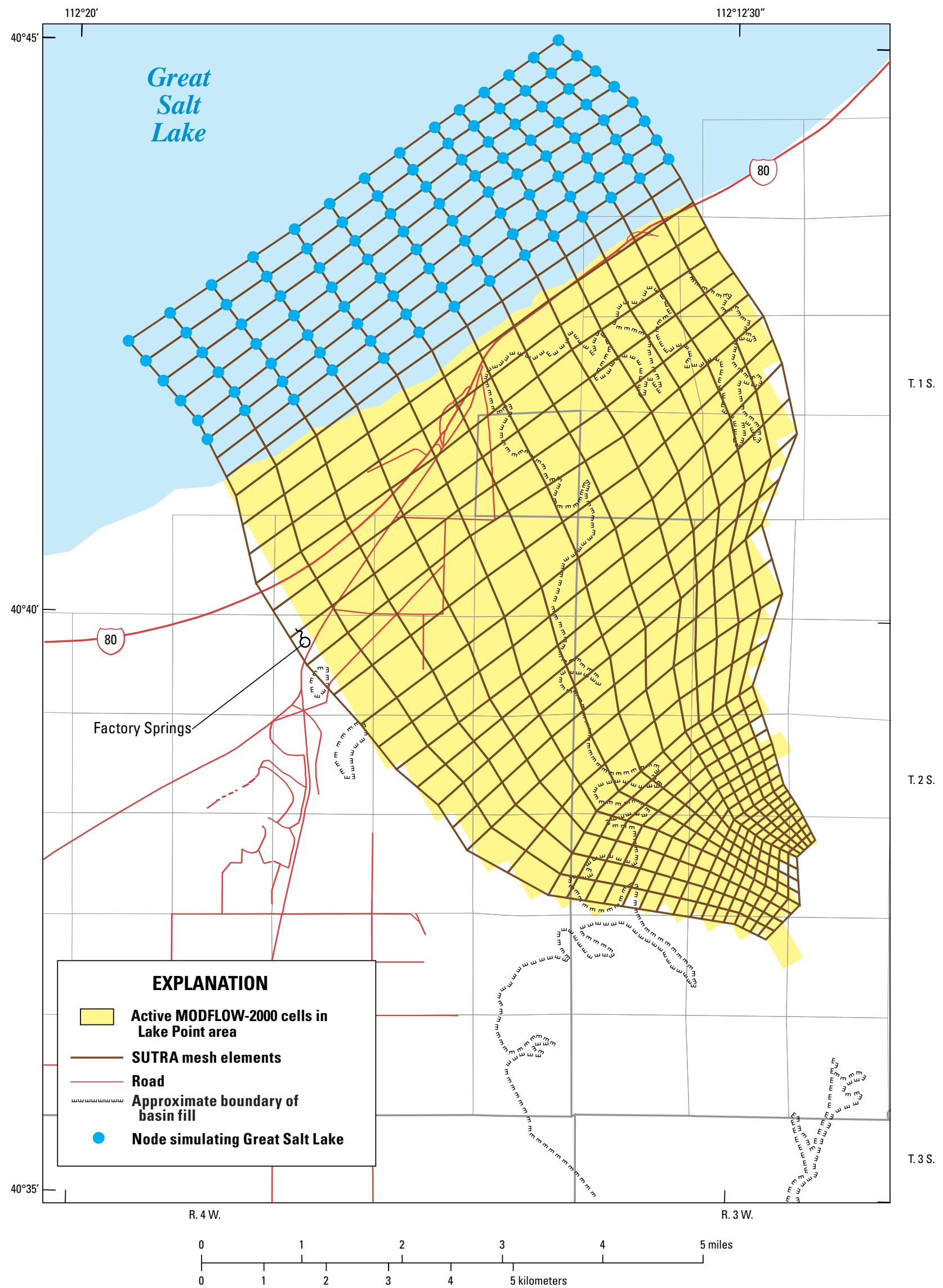

Figure 12. Relation of SUTRA mesh to MODFLOW-2000 grid and location of SUTRA nodes simulating Great Salt Lake, Lake Point, Tooele County, Utah. 
Tooele Valley MODFLOW-2000 model were converted to the SI system for the SUTRA model.

To simulate the dissolved-solids concentration of ground water in Lake Point under 2002 advective flow conditions, the SUTRA model was run as a transient simulation allowing small changes in dissolved-solids concentration until steadystate conditions were reached. The simulation started with the MODFLOW simulated heads (as pressure) and the concentration of Great Salt Lake at all cells vertically below Great Salt Lake. The ending time was extended until concentrations were steady at most nodes. Simulated dissolved-solids concentration along the southwestern edge of the model (fig. 13) indicate the amount of mixing that occurs at the interface. No water with concentration as high as the concentration of Great Salt Lake water intrudes into the valley, but water with a dissolved-solids concentration exceeding 30,000 mg/L extends about $1.5 \mathrm{mi}$ south of Great Salt Lake beneath the valley.

Because concentration is related to dispersivity and effective porosity, different values of those parameters were simulated and the differences in final concentrations were observed. A longitudinal dispersivity of $100 \mathrm{~m}$ yields a numerically instable model with areas of dissolved-solids concentration below 0 and areas near Great Salt Lake that have less dissolved-solids concentration than areas farther from the lake. A longitudinal dispersivity of $400 \mathrm{~m}$ eliminated most of the numerically instable areas, but otherwise yielded a similar distribution of dissolved-solids concentration as a longitudinal dispersivity of $100 \mathrm{~m}$. Transverse dispersivity was set at $10 \mathrm{~m}$ and was not varied. Effective porosity was simulated at both 0.1 and 0.01 . The final distribution of dissolved-solids concentration was similar, but the time to reach steady concentrations was different. With porosity equal to 0.1 , concentrations stabilized in about 1,900 to 2,500 years. With porosity equal to 0.01 , concentrations stabilized in about 1,000 years.

Although the MODFLOW model reasonably matches measured water levels and the conceptual water budget, and the distribution of dissolved-solids concentration simulated by the SUTRA model appears reasonable, the SUTRA model should not be considered a calibrated variable-density model of the Lake Point area. It has been developed to test hypothetical situations and not to yield calibrated predictions of changes in ground-water quality.

The simulation generates a reasonable approximation of 2002 dissolved-solids concentration (fig. 14). At most locations with measured dissolved-solids concentration in excess of $1,000 \mathrm{mg} / \mathrm{L}$, the model simulates salt-water intrusion with similar concentration. Local exceptions are wells (C-14)36ccb-1, -2, and -3 and wells (C-2-4)10bda- 1, -2, and -3 .

The set of nested wells in (C-1-4)36ccb is on the eastern edge of Lake Point near consolidated rock. Water from these wells has dissolved-solids concentration of about 1,000, 1,200, and $5,200 \mathrm{mg} / \mathrm{L}$, respectively. The largest concentration is in the deepest well, which is completed in consolidated rock. The SUTRA simulation does not indicate salt-water intrusion in any of the three wells. It is possible that a geologic source is causing the large dissolved-solids concentration or that ground-water flow in this area of complicated geology is not simulated correctly. In the MODFLOW model, this area has higher residuals between simulated and observed water levels than most other areas, which indicates that the ground-water flow system may not be represented correctly in the groundwater flow models.

A geologic source for the dissolved-solids concentration in water from the wells in (C-2-4)10bda near Adobe Rock also is indicated. The specific conductance of $35,800 \mu \mathrm{S} / \mathrm{cm}$ reported for water from the deepest well is more than twice the highest specific-conductance value reported for Factory Springs (Kenney and others, 2006). The amount of flow moving through the system to Factory Springs should inhibit salt-water intrusion inland from Factory Springs and make it unlikely to have higher dissolved-solids concentration values at the wells than at the springs. The area is, however, geologically and hydrologically complex, and fracture flow or other high-conductivity zones could exist that are not simulated.

The second SUTRA simulation used the flow-boundary conditions from projection 1 of the regional model, including an additional 1,050 acre-ft/yr of proposed ground-water withdrawal. The ending pressures and concentration from the first SUTRA simulation were used as initial conditions. The third SUTRA simulation used the flow-boundary conditions from projection 2 of the regional model, including 1,650 acre- $\mathrm{ft} / \mathrm{yr}$ of proposed ground-water withdrawal. The ending pressures and concentration from the first SUTRA simulation were used as initial conditions. Both projections were simulated with effective porosity equal to 0.1 and 0.01 for 1,500 years to approach steady-state conditions. Maximum steady concentrations typically occur after simulating 500 to 800 years of increased withdrawal with porosity equal to 0.1 and after simulating about 170 years of increased withdrawal with porosity equal to 0.01 . In addition to porosity, hydraulic conductivity and storage coefficient also will affect salt-water travel times. These effects were not analyzed during this study.

Final dissolved-solids concentration from the projection simulations were compared with concentration simulated for 2002 steady-state conditions for the bottoms of MODFLOW2000 regional model layers 2 and 4 . The bottom of model layer 2 is about $250 \mathrm{ft}$ below simulated water levels, and about 250 to $300 \mathrm{ft}$ below land surface in much of Lake Point. It probably corresponds to or is deeper than most domestic wells. Simulated dissolved-solids concentration throughout much of Lake Point and near Factory Springs at the bottom of layer 2 ranges from 200 to $1,000 \mathrm{mg} / \mathrm{L}$ greater than without increased withdrawals (fig. 15). The increase in concentration does not extend south to areas undergoing new residential development. The bottom of layer 4 is about $700 \mathrm{ft}$ below the simulated water surface and corresponds to the zone of completion of the new production wells. The increase in dissolved-solids concentration with increased withdrawals is much greater at the bottom of layer 4 than at the bottom of layer 2 and exceeds $1,000 \mathrm{mg} / \mathrm{L}$ throughout most of Lake Point (fig. 16). At the north end of Lake Point, increases exceed 10,000 mg/L. The increase in concentration extends south farther than in layer 2. 

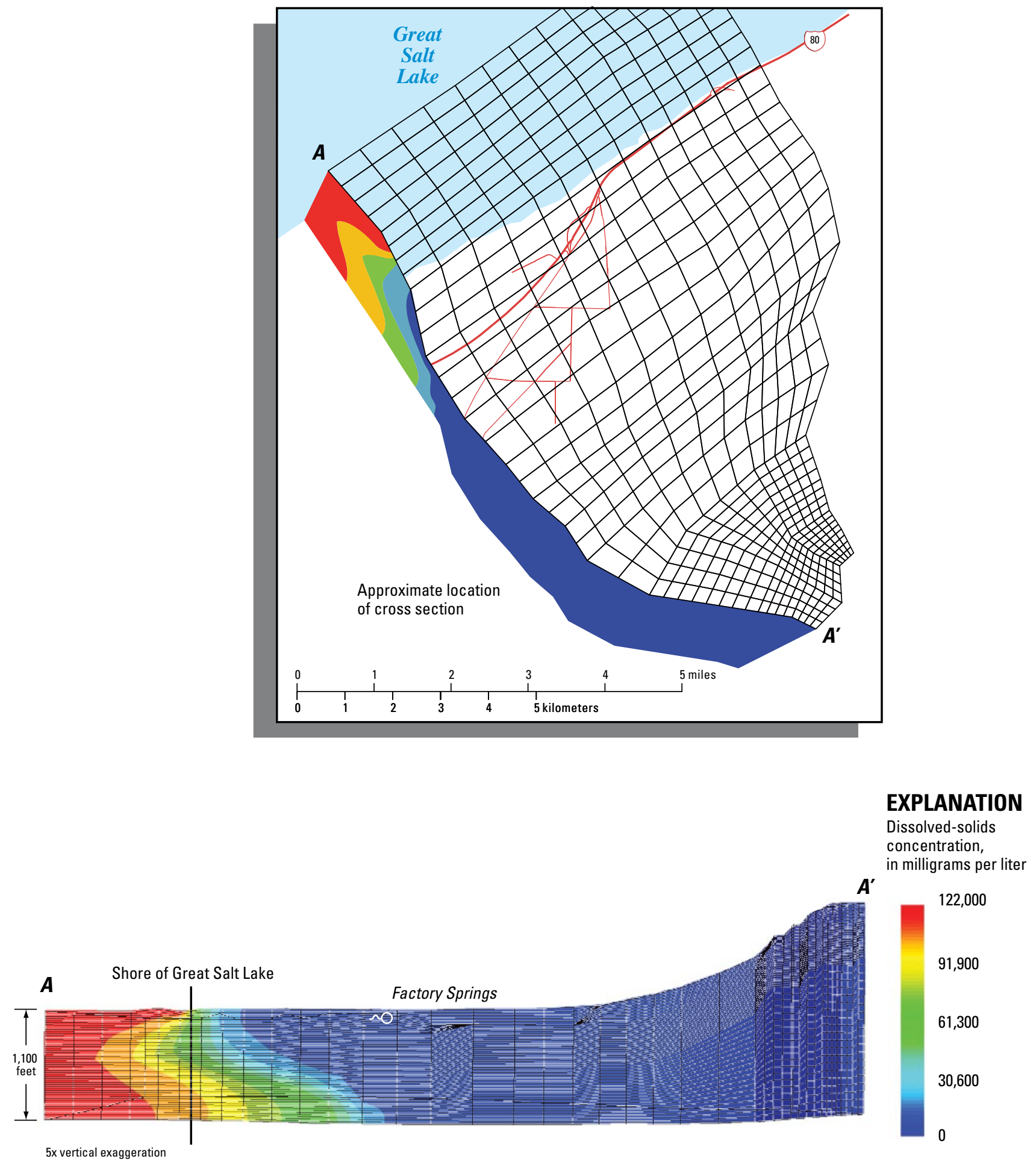

Figure 13. Simulated dissolved-solids concentration in ground water caused by salt-water intrusion with 2002 flow conditions, Lake Point area, Tooele County, Utah. 


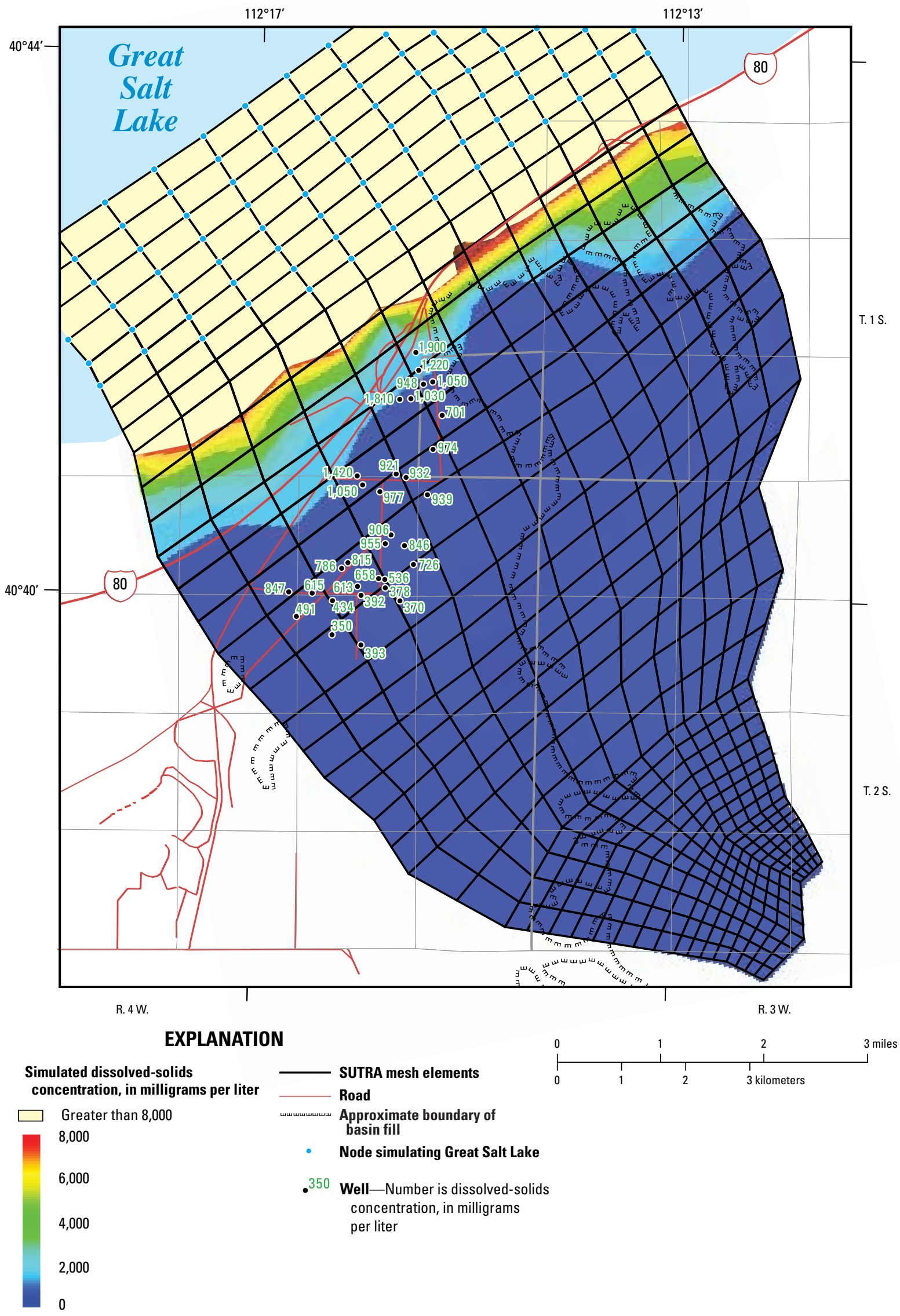

Figure 14. Simulated steady-state and 2002 measured dissolved-solids concentration, Lake Point area, Tooele County, Utah. 


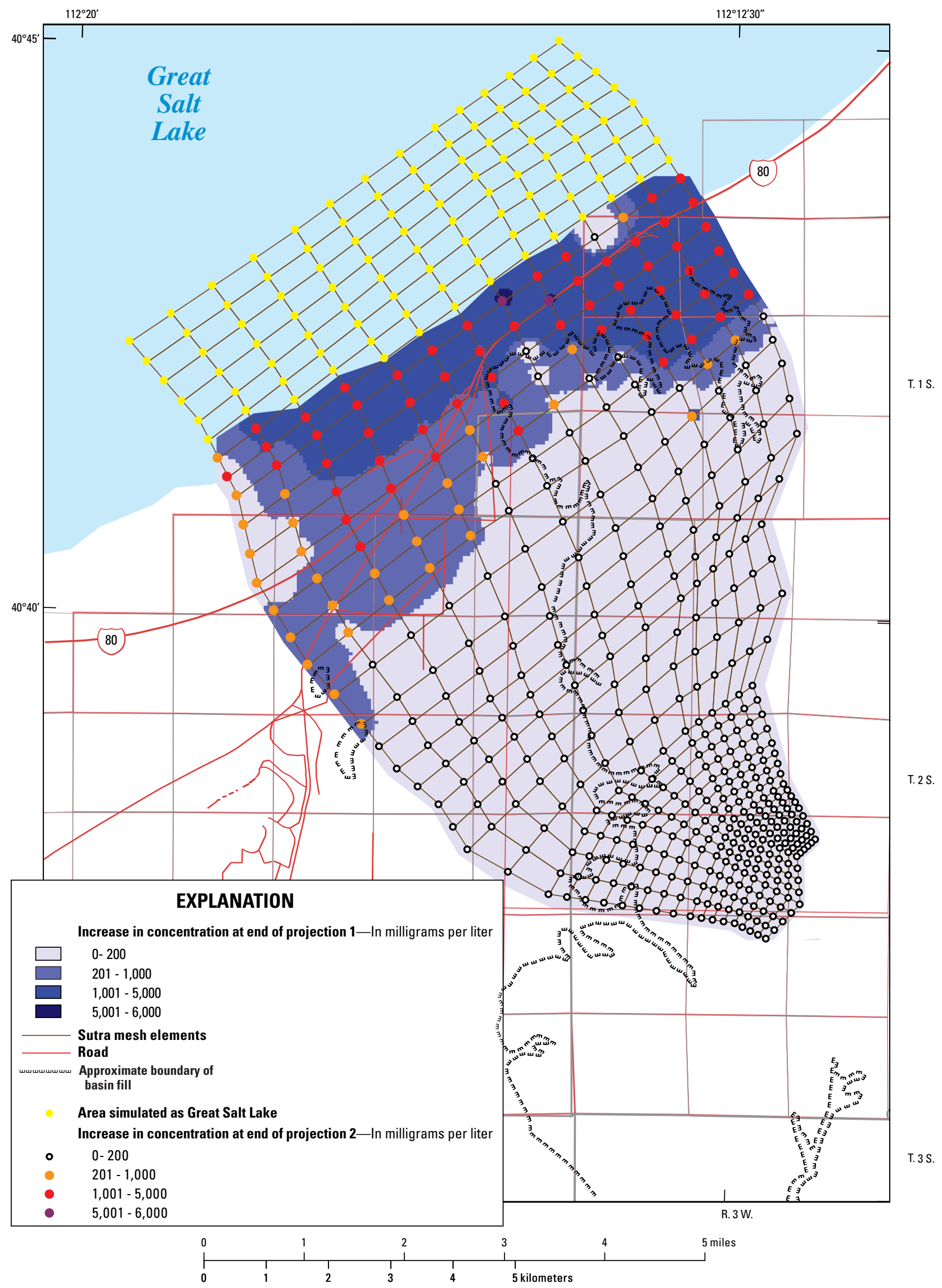

Figure 15. Simulated increase in dissolved-solids concentration over 2002 steady-state conditions caused by increasing withdrawals, bottom of model layer 2, Lake Point area, Tooele County, Utah. 


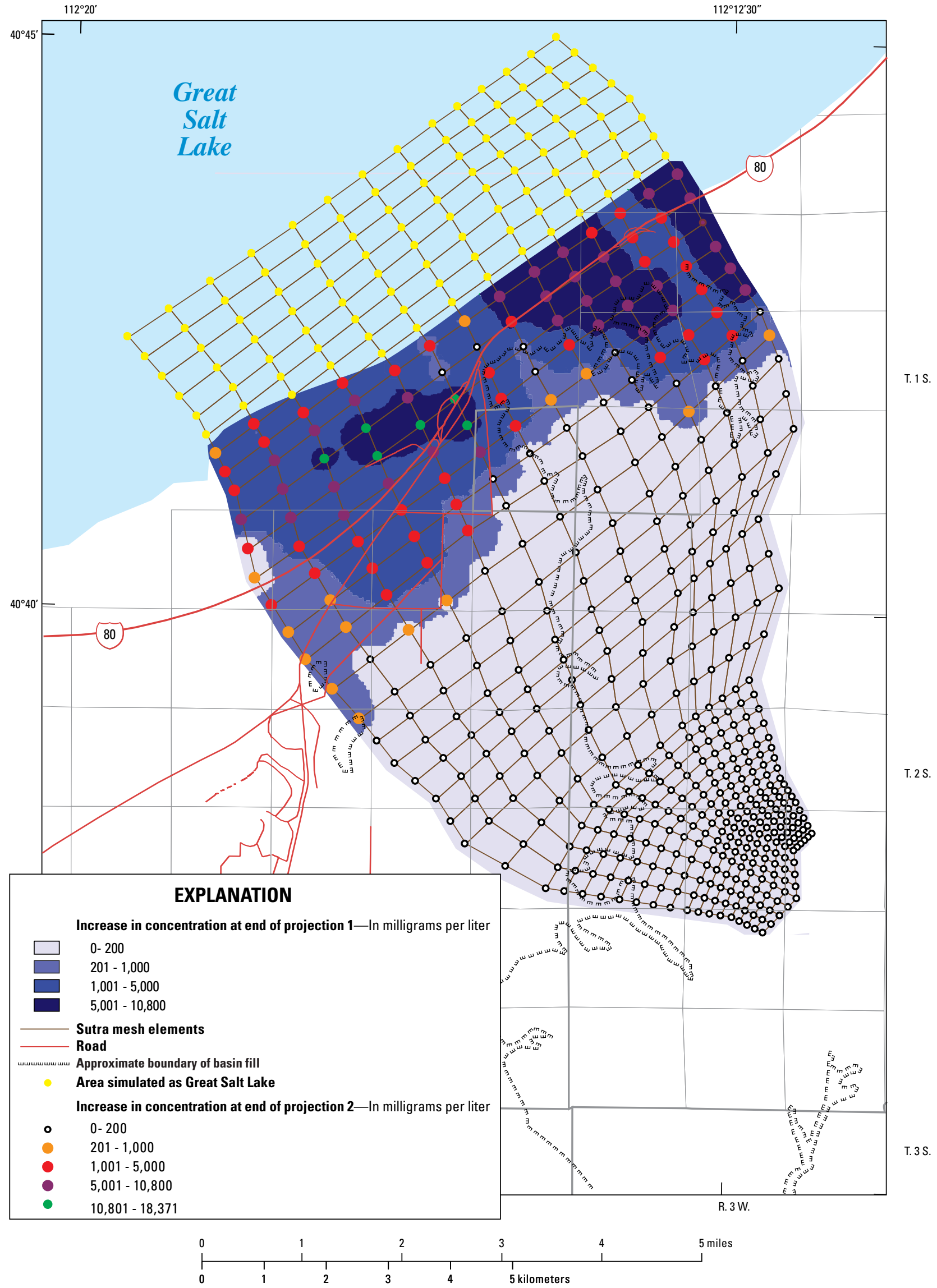

Figure 16. Simulated increase in dissolved-solids concentration over 2002 steady-state conditions caused by increasing withdrawals, bottom of model layer 4, Lake Point area, Tooele County, Utah. 
Projection 2 simulates higher concentrations than projection 1 , especially at the north end of Lake Point and north of Factory Springs (figs. 15 and 16). Because the regional MODFLOW2000 model accurately simulates water levels and groundwater movement and the steady-state Lake Point area SUTRA model reasonably simulates observed dissolved-solids concentration, the simulated degradation in water-quality caused by increased withdrawal is probably a reasonable approximation of salt-water intrusion that may occur as a result of increased withdrawals.

Some of the largest increases in dissolved-solids concentration occur in the area north of the Oquirrh Mountains. Unfortunately, this geologically complex area may not be accurately simulated in the models, as indicated by high residuals in the MODFLOW-2000 simulation (fig. 8). It is possible, however, that the increased withdrawals will capture water that previously was flowing north in the Oquirrh Mountains (figs. 9 and 10). The decreased flow to the lake would result in increased salt-water intrusion in the area north of the Oquirrh Mountains.

\section{Summary}

Lake Point is experiencing growth and potential largescale residential development as a bedroom community of Salt Lake City, Utah. The U.S. Geological Survey (USGS), in cooperation with Tooele County; Utah Department of Natural Resources, Division of Water Rights; and Lake Point Improvement District investigated the ground-water hydrology of Lake Point to provide knowledge for management of the area's ground-water resources. Some of the water for new residential development may be supplied by public-supply wells completed in consolidated rock on the east side of Lake Point. To help understand the effect the proposed withdrawal will have on water levels, flowing-well discharge, spring discharge, and salt-water intrusion from Great Salt Lake in Lake Point, ground-water flow models were developed.

Ground-water recharge in Lake Point occurs from local precipitation and irrigation, and as subsurface inflow from southwest of the area. Ground-water discharge in Lake Point is mostly to Factory Springs. Other discharge is to Great Salt Lake, by evapotranspiration, to wells, and as subsurface outflow to the west of the study area, and composes about 30 percent of the discharge in Lake Point. Even though ground water discharges to Great Salt Lake, dense salt water from the lake intrudes under the less-dense ground water and forms a salt-water wedge beneath the valley. This salt water is responsible for some of the high dissolved-solids concentration values measured in ground water in Lake Point.

The steady-state ground-water flow model adequately simulates water levels observed in Lake Point in 1969 and 2002 and ground-water discharge. Ground-water flow direction indicated by contours of simulated water-level altitude is similar to ground-water flow direction indicated by con- tours of measured water-level altitude. Similarities between simulated and measured water levels indicate that simulated recharge, discharge, and distribution of hydrologic properties adequately represent the ground-water system. The groundwater flow model was used to estimate possible effects on water levels and spring discharge caused by increased withdrawal from wells completed in the consolidated rock on the east side of Lake Point.

In projection 1, drawdown in most of the developed part of Lake Point ranges from 2 to $6 \mathrm{ft}$. Drawdown in the consolidated rock east of the increased withdrawal exceeds $30 \mathrm{ft}$ over a large area. Discharge to Factory Springs, flowing wells, evapotranspiration, and Great Salt Lake is decreased by about 700 acre-ft/yr (17 percent). In projection 2, drawdown in most of the developed part of Lake Point ranges from 2 to $10 \mathrm{ft}$, but increases to more than 40 feet in the areas proposed for residential development south and east of Lake Point. Drawdown in the consolidated rock east of the increased withdrawal exceeds $80 \mathrm{ft}$ over an area encompassing most of the Oquirrh Mountains east of Lake Point. Discharge to Factory Springs, flowing wells, evapotranspiration, and Great Salt Lake is decreased by about 1,100 acre-ft/yr ( 25 percent). The projections indicate that more than 50 percent of the water for the proposed withdrawals is supplied by decreasing discharge from Factory Springs.

Numerical simulation of the ground-water system including variable-density flow was used to estimate the current pattern of salt-water intrusion, the zone of mixing, and whether additional ground-water development in Lake Point will lower water levels enough to allow salt water to intrude farther. The USGS SUTRA model was used for three simulations. The first simulation simulated the dissolved-solids concentration of ground water in Lake Point under 2002 advective flow conditions. The simulation generates a reasonable approximation of 2002 dissolved-solids concentration. The second simulation includes an additional 1,050 acre-ft/yr of ground-water withdrawal, and the third simulation includes an additional 1,650 acre-ft/yr of ground-water withdrawal.

With increased withdrawals, simulated dissolved-solids concentration throughout much of Lake Point and near Factory Springs ranges from 200 to $1,000 \mathrm{mg} / \mathrm{L}$ greater at depths of about $300 \mathrm{ft}$ than without increased withdrawals. The increase in concentration does not extend south to areas undergoing new residential development. The increase in dissolved-solids concentration throughout most of Lake Point exceeds 1,000 $\mathrm{mg} / \mathrm{L}$ at depths of about 700 feet and extends farther south than at shallower depths. At the north end of Lake Point, the increase in concentration exceeds $10,000 \mathrm{mg} / \mathrm{L}$. Projection 2 simulates higher concentrations than projection 1 , especially at the north end of Lake Point and north of Factory Springs. 


\section{References Cited}

Domenico, P.A., and Schwartz, F.W., 1990, Physical and chemical hydrogeology: New York, John Wiley and Sons, $824 \mathrm{p}$.

Freeze, R.A., and Cherry, J.A., 1979, Groundwater: Englewood Cliffs, New Jersey, Prentice-Hall, 604 p.

Gates, J.S., 1965, Reevaluation of the ground-water resources of Tooele Valley, Utah: Utah State Engineer Technical Publication No. 12, 68 p.

Glover, R.E., 1964, The pattern of fresh-water flow in a coastal aquifer, in Cooper, H.H., Jr., Kohout, F.A., Henry, H.R., and Glover, R.E., Sea water in coastal aquifers: U.S. Geological Survey Water-Supply Paper 1613-C, p. C32C35.

Harbaugh, A.W., 1990, A computer program for calculating subregional water budgets using results from the U.S. Geological Survey modular three-dimensional finite-difference ground-water flow model: U.S. Geological Survey OpenFile Report 90-392, 46 p.

Harbaugh, A.W., Banta, E.R., Hill, M.C., and McDonald, M.G., 2000, MODFLOW-2000, The U.S. Geological Survey modular ground-water model — User guide to modularization concepts and the ground-water flow process: U.S. Geological Survey Open-File Report 00-92, 121 p.

Hill, M.C., Banta, E.R., Harbaugh, A.W., and Anderman, E.R., 2000, MODFLOW-2000, The U.S. Geological Survey modular ground-water model - User guide to the observation, sensitivity, and parameter-estimation processes and three post-processing programs: U.S. Geological Survey Open-File Report 00-184, 209 p.

Kenney, T.A., Wright, S.J., and Stolp, B.J., 2006, Groundwater movement and water quality in Lake Point, Tooele County, Utah: U.S. Geological Survey Scientific Investigations Report 2006-5124, 13 p.

Lambert, P.M. and Stolp, B.J., 1999, Hydrology and simulation of the ground-water flow system in Tooele Valley, Utah: U.S. Geological Survey Water-Resources Investigations Report 99-4014, 60 p.

Prism Group, Oregon State University, 2003, Prism products matrix, accessed April 9, 2003, at http://www.ocs.orst.edu/ $\mathrm{prism} /$ products $/$ matrix.phtml vartype $=$ tmax $\&$ view $=$ maps

Voss, C.I. and Provost, A.M., 2002, SUTRA: A model for saturated-unsaturated, variable-density ground-water flow with solute or energy transport: U.S. Geological Survey Water-Resources Investigations Report 02-4231, 250 p.
Wilberg, D.E., Tibbetts, J.R., and Enright, Michael, 2003, Water Resources Data-Utah, Water Year 2002: U.S. Geological Survey Water-Data Report UT-02-1, 391 p. 
Hydrology and Simulation of Ground-Water Flow, Lake Point, Tooele County, Utah 


\section{趈}

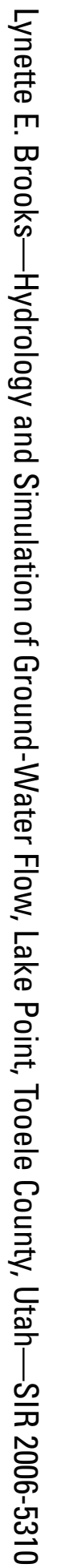

